\title{
THERMOCHRONOLOGIC CONSTRAINTS ON THE ORIGIN OF THE GREAT UNCONFORMITY
}

NON-PEER REVIEWED PREPRINT SUBMITTED TO EARTHARXIV, COMPILED OCTOBER 17, 2021

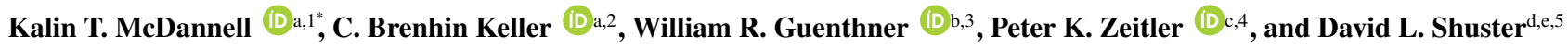

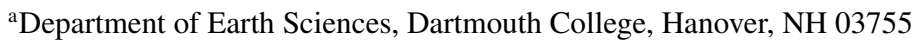 \\ ${ }^{b}$ Department of Geology, University of Illinois at Urbana-Champaign, Urbana, IL 61801 \\ ${ }^{c}$ Department of Earth \& Environmental Sciences, Lehigh University, Bethlehem, PA 18015 \\ ${ }^{\mathrm{d}}$ Department of Earth \& Planetary Science, University of California, Berkeley, CA 94720 \\ ${ }^{\mathrm{e}}$ Berkeley Geochronology Center, Berkeley, CA 94709
}

\begin{abstract}
The origin of the phenomenon known as the Great Unconformity has been a fundamental yet unresolved problem in the geosciences for over a century. Recent hypotheses advocate either global continental exhumation of more than 3-4 km during Cryogenian (717-635 Ma) snowball Earth glaciations, or alternatively, diachronous episodic exhumation throughout the Neoproterozoic (1000-540 Ma) due to plate tectonic reorganization from supercontinent Rodinia assembly and breakup. To test these hypotheses, the temporal pattern of Neoproterozoic thermal histories were evaluated for four North American locations using previously published medium-to-low temperature thermochronology and geologic information. We present inverse time-temperature simulations within a Bayesian modelling framework that record a consistent signal of relatively rapid, high magnitude cooling of $\sim 120-200^{\circ} \mathrm{C}$ interpreted as erosional exhumation of upper crustal basement during the Cryogenian. These models imply widespread, synchronous cooling consistent with at least $\sim 3-5 \mathrm{~km}$ of unroofing during snowball Earth glaciations, but also demonstrate that plate tectonic drivers, with the potential to cause both exhumation and burial, may have significantly influenced the thermal history in regions that were undergoing deformation concomitant with glaciation. In the cratonic interior, however, glaciation remains the only plausible mechanism that satisfies the required timing, magnitude, and broad spatial pattern of continental erosion revealed by our thermochronological inversions. To obtain a full picture of the extent and synchroneity of such erosional exhumation, studies on stable cratonic crust below the Great Unconformity must be repeated on all continents.
\end{abstract}

Keywords Great Unconformity · snowball Earth · thermochronology · North America · glacial erosion

\section{Significance}

The Great Unconformity represents a gap of hundreds of millions to over a billion years in the geologic record. The cause of this missing time has eluded explanation, yet recently two opposing hypotheses claim either a glacial or plate tectonic origin in the Neoproterozoic. We provide thermochronologic evidence of rock cooling and multiple kilometers of exhumation in the Cryogenian Period in support of a glacial origin for the composite basement nonconformity found across the North American interior. The broad synchronicity of this cooling signal at the continental scale can only be readily explained by glacial denudation. below [4]. The presence of the Great Unconformity in the rock record is significant because the erosion required to create the unconformity and the widespread burial that preserved it are both equally important. The crucial defining feature of the Great Unconformity is that erosion occurred across a vast area, especially the cratonic interior. The most quantitative reflection of this feature is arguably provided by the coeval step-wise increase in preserved sediment abundance per unit time across the unconformity - a step change first accurately quantified by Ronov and coauthors [7, 8, 9], and observed on every continent with the possible exception of Africa. This five-fold discontinuity in global preserved sediment abundance [8] suggests profound changes in both erosional and depositional processes [5], and in any event provides a quantitative metric for the significance of the Great Unconformity as a global feature.

The Great Unconformity is, however, far from the only significant phenomenon associated with the emergence of the Phanerozoic world. The transitional Neoproterozoic era saw several significant changes in the Earth system, including the gradual breakup of the supercontinent Rodinia from $\sim 825 \mathrm{Ma}$ to $\sim 570 \mathrm{Ma}[10,11,12]$, possibly significant fluctuations in atmospheric oxygen [13], and two severe failures of Earth's silicate weathering feedback [14] within the Cryogenian Period (717-635 Ma) that glaciated the continents down to the equator $[15,16]$. This interval culminated in the Ediacaran Period (635-540 $\mathrm{Ma}$ ) when the appearance of a more diverse biosphere [e.g., 17], especially macroscopic multicellular organisms, set the stage for the dramatic diversification of visible metazoan life in the earliest Cambrian $[18,19,20]$. Perhaps the most marked and non-uniformitarian of these events were the hypothesized low-latitude glaciations [21, 15, 16]. Maximization of silicate weathering sensitivity due to concentration of Rodinian continents near the equator favored ice-house conditions, and be that which separates rocks containing abundant macrosc name of Earth's current geological Eon-the Eon of visible Phanerozoic. For nearly as long as the significance of this dividi has been appreciated, and before the name Phanerozoic was yet occurrence of one or more significant unconformities below the oldest rocks containing abundant macroscopic fossils [2]. This phenomenon, taking its name from a particularly charismatic occurrence at Gran Canyon [3], has subsequently been referred to by some authors as the Great Unconformity [e.g., 4, 5]. While lacunae in the geologic record are common [6], those below the oldest rocks of the Phanerozoic are frequently large-in many cases even juxtaposing undeformed sedimentary rocks above, with crystalline igneous or metamorphic basement 
glaciation is thought to have initiated when sea ice advanced within $\sim 40^{\circ}$ of the equator [22]. The sea-ice/albedo positive feedback overwhelmed the silicate weathering negative feedback and continental glaciations extended to low latitudes in three episodes, the Sturtian (717-659 Ma), Marinoan (641-635), and Gaskiers ( 580 Ma)—of which the Sturtian and Marinoan were global 'snowball Earth' events $[15,16,23,24,22]$. The proximal trigger for all three glaciations, however, remains a matter of debate $[25,26,27]$.

Recently, Keller et al. [5] proposed that widespread erosion by continental ice sheets during these Neoproterozoic glacial intervals may be responsible for the anomalous concentration of unconformities at the end of the Precambrian. If correct, a link between continental glaciation and kilometer-scale cratonic exhumation would have dramatic implications for our understanding of the long-term preservation, composition (via increased sediment subduction and relamination), and freeboard of continental lithosphere, and could help explain a wide set of puzzling observations across several related disciplines [5] -including the much-discussed increase in apparent high-latitude terrigenous sediment flux coincident with Laurentide glaciation [e.g., 28]. However, this proposal has not been without controversy [e.g., 29, 30, 31]. While some of this controversy may be attributable to differences in termi nology, significant points of contention remain-primarily, whether Neoproterozoic glaciation did or did not cause significant upper crustal exhumation. Resolving these differences is critical to our understanding of the Neoproterozoic Earth system and the couplings and feedbacks between tectonic, climatic, and biogeochemical processes therein.

Over the past century, the term 'Great Unconformity' has acquired multiple loaded meanings. Historically, the term was first applied by Clarence Dutton [3] from the rim of the Grand Canyon (USA) to the unconformity at the base of the flat-lying Phanerozoic sedimentary succession within (in some regions a disconformity and in other regions a nonconformity) - though at the time, Dutton did not yet know the true age of the rocks involved. Subsequently, it has been variously used to denote one or more of the following:

I. An unconformity at or near the base of the Phanerozoic, that is separating rocks that contain visible fossils from those that do not [e.g., 2], either in general or at a specific locality.

II. A basement nonconformity, either in general or at a specific locality, often with the (perhaps implicit) additional requirement that the involved basement be Precambrian in age [e.g. 32, 29]; or

III. A broader phenomenon evidenced qualitatively by the observation $[2,4]$ that (I) and (II) frequently coincide (especially relative to what one might expect by chance), suggesting the existence of a globally widespread exposure surface [e.g., 4, 5] - an inference quantitatively confirmed by the global step in preserved sediment abundance first observed by Ronov [8].

This variation in meaning invites confusion and controversy as to the synchroneity or diachroneity of the Great Unconformity, depending on which (or which combination) of the above meanings is intended. On one hand, individual physical unconformity surfaces are ubiquitously composite in origin, with later episodes of erosion capturing and subsuming previous erosional surfaces. On the other hand, the set of unconformities spanning the base of the Phanerozoic (i.e., I) are in a sense synchronous by definition, as is consequently, to some extent, the broader phenomenon implied in III. Thus, we apply 'Great Unconformity' to the temporal correlation of unconformities in the late Precambrian (III), whereas for example, the usage in Flowers et al. [29] is more aligned with (II) — asserting diachronous worldwide development of many 'Great Unconformities' in the Neoproterozoic.
After accounting for such semantic differences, remaining points of disagreement center on the question of whether or not Neoproterozoic glaciations were significantly erosive. Relatedly, while in no means mutually exclusive with glacial erosion, it also remains entirely worthwhile to quantify the relative contributions to Neoproterozoic crustal exhumation in different regions from such known tectonic events as Rodinia assembly, Rodinia breakup, and Pan-African orogeny. In principle, thermochronology, which allows us to determine time-temperature (and thus exhumation) histories, is well-suited to resolve such questions However, recent attempts [29, 30, 31], taken individually, fall short of truly resolving the critical questions.

Firstly, the uncertainty of time-temperature $(t-T)$ paths derived from a single thermochronometer can be large for older rocks-a problem sometimes exacerbated by the use of suboptimal inversion methodologies-making it difficult to discern between glacial and tectonic drivers by timing alone. Secondly, the magnitude of both glacial and tectonic erosion are expected to be spatially heterogeneous. Fortunately, however, glacial and tectonic processes predict distinct spatial patterns of exhumation - with tectonic erosion focusing in tectonically active regions near cratonic margins, and ice-sheet glacial erosion focusing in regions of wet-based ice-namely, in the models of Donnadieu et al. [33], broad regions of the low-latitude cratonic interiors away from ice divides, narrowing to a more 'hit-or-miss' pattern at cratonic margins where basal slip is focused into only a few rapid outlet ice streams - as is observed at modern Greenland and Antarctic ice margins. Consequently, in order to resolve the relative contributions of all such climatic and tectonic drivers of erosion in the Neoproterozoic, not to mention their potential interactions, we require higher-resolution $t-T$ paths from localities that can address the spatial pattern of Neoproterozoic exhumation at a global scale. Here we report robust Bayesian thermochronological inversions to test these hypotheses and our results show a widespread pattern of nearly synchronous Cryogenian rock cooling across North America that is interpreted as multiple kilometers of erosional exhumation due to ice-sheet glaciation.

\section{DEEP-TIME THERMOCHRONOLOGY}

Thermochronology allows us to estimate the temperature that a mineral crystal has experienced over time, and its position in the continental crust given a particular thermal structure. It provides a potential test for the contrasting hypotheses regarding the proposed link between widespread glaciation and cratonic exhumation, specifically linking snowball Earth glaciations to the phenomenon of widespread unconformity spanning the late Neoproterozoic. The use of multiple thermochronometers with varying temperature sensitivities is critical for such deep-time applications, because the parameter space of possible $t$ $T$ paths only grows with increasing time scale [34]. Moreover, although a multichronometer approach can be time- and resource-intensive, the improved resolution critically allows for model results to be independently validated by testing against known geologic constraints, rather than merely forcing the model to fit such constraints a priori.

Recent reports in the thermochronologic literature indicate that nearly continuous thermal histories can be constrained using a multi-method approach $\left(400^{\circ} \mathrm{C}\right.$ and lower) that involves jointly inverting these data to effectively explore Precambrian histories, supplemented by existing high-temperature metamorphic data and stratigraphic constraints [e.g., $35,36,37,34]$. In this context, the inclusion of medium-temperature $\left(100-300^{\circ} \mathrm{C}\right)$ thermochronometers such as K-feldspar ${ }^{40} \mathrm{Ar} /{ }^{39} \mathrm{Ar}$ and zircon $(\mathrm{U}-\mathrm{Th}) / \mathrm{He}$ are especially important, since low-temperature systems $\left(<100^{\circ} \mathrm{C}\right)$ tend to record only the most recent Phanerozoic overprints from burial reheating. A robust multichronometer approach featuring a full range of temperature sensitivities, however, should allow us to see past such overprints and accurately constrain the erosion history 
of ancient crystalline basement over $\sim$ Ga timescales. To this end, we consider the following range of thermochronometers:

\section{Potassium feldspar ${ }^{40} \mathrm{Ar} /{ }^{\beta 9} \mathrm{Ar}$ dating}

Potassium feldspar is notable for its ubiquity in crustal rocks, for containing appreciable amounts of radiogenic argon, and for containing domains of differing diffusion radius [38]. The degassing behavior of domains can be characterized during laboratory ${ }^{40} \mathrm{Ar} /{ }^{39} \mathrm{Ar}$ step-heating experiments and mathematically modeled to determine the number of domains, relative size distribution, and kinetic parameters specific to each sample [39]. This information can in turn be inverted to yield a continuous thermal history record between $\sim 350-150^{\circ} \mathrm{C}[40,34]$ and provides a crucial link between high- and low-temperature thermochronometers.

\section{Zircon $(\mathrm{ZHe})$ and apatite $(\mathrm{AHe})(\mathrm{U}-\mathrm{Th}) / \mathrm{He}$ dating}

Helium diffusivity in zircon and apatite is modulated by accrued alpharadiation damage from radioactive decay in the crystal lattice [e.g 41, 42, 43]. Higher radiation damage in apatite correlates with higher He retentivity (i.e., lower diffusivity; 41). High U zircon grains with greater radiation damage experience faster He diffusion rates over geologic time, whereas the opposite is true for low $\mathrm{U}$ grains. Heating of these minerals causes annealing of accumulated radiation damage. Given certain $t-T$ conditions and mineral chemistries, radiation damage effects manifest as large intra-sample He date variation. Individual grains accumulate a predictable amount of radiation damage as a function of their $\mathrm{U}$ and Th concentration and $t-T$ path, and multiple grains from the same sample with different $U$ and Th concentrations will therefore each have a different respective He diffusivity and behave as an independent thermochronometer. The 'effective uranium' of any grain can be represented by the single parameter eU $(=[\mathrm{U}]+0.238 \times[\mathrm{Th}]+0.0012 \times[\mathrm{Sm}] ; 44)$, which weights the He contribution from each parent by its alpha-decay productivity. Date-eU trends provide much more powerful and informative thermal history information than any one date [45, 34]. The use of many single-crystal dates provides useful information that can be inverted for thermal history, often spanning $\sim 200-40^{\circ} \mathrm{C}$ over a range of $<100 \mathrm{ppm}$ to $>2000 \mathrm{ppm}$ $\mathrm{eU}$ for zircon, and $\sim 100-50^{\circ} \mathrm{C}$ over $<10 \mathrm{ppm}$ to $<200 \mathrm{ppm}$ eU for apatite grains.

\section{Apatite fission-track (AFT) dating}

The AFT method is sensitive to temperatures between $\sim 110-60^{\circ} \mathrm{C}$ for most rocks that incorporate common apatite, and for this reason is useful for determining upper crustal erosion and burial histories. Fission-track dating is based on quantifying (counting) the damage trails created from the energetic fission of ${ }^{238} \mathrm{U}$, which happens continuously at a known rate in the mineral crystal lattice [e.g., 46]. These 'fission tracks' are then related to the amount of uranium present in a counted grain area to calculate an apparent 'age' for an apatite grain, or approximate time over which appreciable fission tracks have accumulated in the crystal [47]. The production of fission tracks is continuous across a sample's thermal history. Tracks initially have an etched length of $\sim 16-17 \mu \mathrm{m}$ and shorten with heating, being totally annealed $>120^{\circ} \mathrm{C}$ [e.g., 48, 49]; thus each track has a different age and records a different portion of the thermal history. Annealing resistance is also influenced by apatite chemical composition, notably $\mathrm{Cl}$ and other elemental substitutions $[50,51]$. Track lengths are measured since they can be used to model the style and magnitude of cooling (or partial reheating) experienced during a rock's thermal history [e.g., 52].

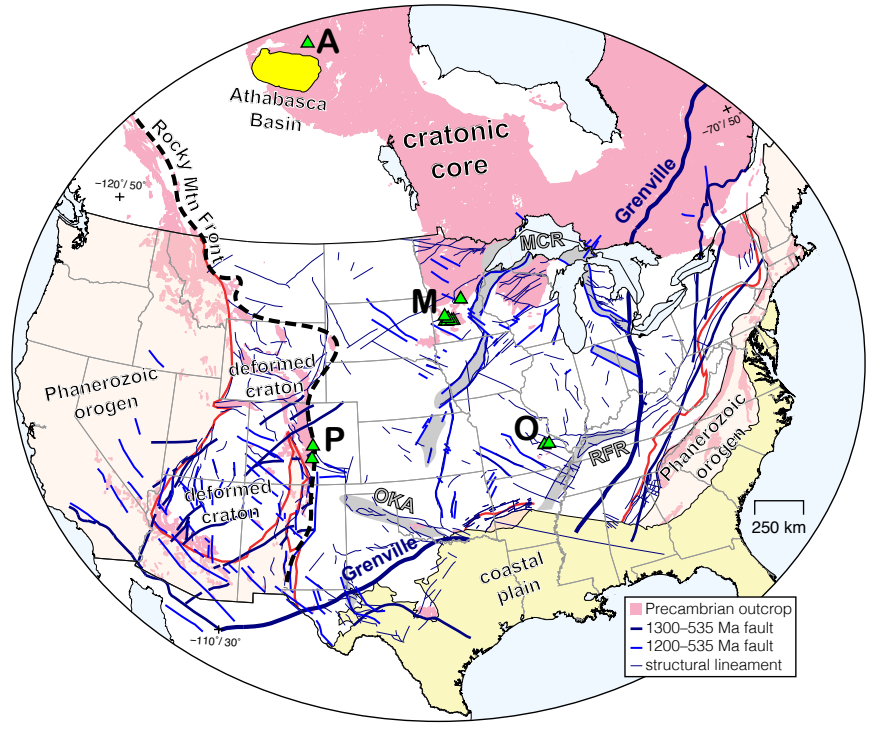

Figure 1: North American location map for previously published thermochronology datasets discussed in this paper. Sample locations (triangles): A = East Lake Athabasca region; $\mathrm{M}=$ Archean Minnesota River Valley terranes; $\mathrm{O}=$ Ozark Mountains; $\mathrm{P}=$ Pikes Peak batholith. Map shows structural and geologic features of the United States and Canada, adapted from Whitmeyer and Karlstrom [57] and Marshak et al. [58]. Precambrian exposed outcrop in pink and Phanerozoic orogens in orange shading. Red lines are the edge of Cenozoic rifting in the west and the Appalachian front in the east from Marshak et al. [58]. Major highlighted rifts (gray) that were active in the mid-late Neoproterozoic. MCR $=$ Midcontinent Rift $;$ OKA $=$ Oklahoma aulacogen; RFR $=$ Reelfoot Rift. Note that regional faults were active in the late Neoproterozoic at the Pikes Peak [e.g., 59, 60] and Ozarks locations [e.g., 61], whereas faulting near the Athabasca and Minnesota samples pre-dated Cryogenian time (i.e., ca. 1.9-1.65 Ga [62] and ca. 1.9 Ga Penokean orogeny and/or 1.1 Ga MCR, respectively).

\section{EVALUATING PUBLISHED THERMOCHRONOLOGY DATA FROM NorTh AMERICA}

We examined previously published thermochronology data from the North American interior spread across the continent to adequately test models of the first-order spatial and temporal pattern of Neoproterozoic crustal exhumation (Fig. 1). Data were compiled from the East Lake Athabasca region (Saskatchewan, Canada) [53, 54, 55], Archean terranes in the Minnesota River Valley (Minnesota, USA) [56, 43], the Ozark Plateau (Missouri, USA) [36], and the Pikes Peak Batholith (Colorado, USA) [29]. The cratonic interior of North America provides an ideal locality for testing the various Great Unconformity formation hypotheses [29] when compared to paleo-margin locations because the craton has remained tectonically stable over the last $\sim 1.8 \mathrm{Ga}$, which alleviates most concerns about more recent, extensive thermal disturbances. In some situations, this allowed us to jointly model samples collected from a broader area of up to $100 \mathrm{~km}$ (i.e., Minnesota), under the assumption that over this scale these cratonic rocks have experienced similar thermal histories.

The QTQt software package [63] was used for Bayesian $t-T$ inversion. Thermal-history modelling is often conducted using a simple Monte Carlo approach by searching for and selecting a subset of "acceptable" paths from a finite set of randomly generated $t-T$ paths [e.g., 64]. However the large parameter spaces of deep-time thermochronology are arguably better suited to a 'guided' inversion methodology such as the reversible-jump Markov chain Monte Carlo (rjMCMC) approach used by QTQt [34]. A key aspect of the rjMCMC method as implemented in QTQt is that the complexity of thermal-history solutions is inferred from the data rather than being defined a priori $[63,65]$. Beyond this, our approach differs from many routine thermochronometric studies by using Bayesian statistical methods for both the search algorithm 
and data uncertainty treatment, the generation of many more $t-T$ paths (several orders of magnitude) during the course of modelling, and a distinctly empiricist philosophy regarding geologic 'constraint box' implementation (Materials and Methods). That is, we greatly minimize the use of such 'constraint boxes' that force the model to take an expected path, allowing us in such cases to instead observe the ability of the model to independently infer geologically plausible paths from the thermochronologic data alone. We present the resulting $t-T$ histories arranged in order from the cratonic interior outward towards the paleo-Laurentian margins (Fig. 1). The more interior locations generally include more thermochronometric systems, longer modeled time intervals, and are characterized by less interpretive complexity (Fig. 2).

\section{East Lake Athabasca, Canadian Shield, Saskatchewan, Canada}

The East Lake Athabasca region lies along the Snowbird Tectonic Zone in the western Canadian Shield at the margin of the remnant ca 1700-1650 Ma Athabasca Basin [67]. High-temperature U-Pb (titanite, apatite, rutile; $\sim 650-400^{\circ} \mathrm{C}$ ) and ${ }^{40} \mathrm{Ar} /{ }^{39} \mathrm{Ar}$ (hornblende, muscovite, biotite; $\sim 550-300^{\circ} \mathrm{C}$ ) geochronology constrain episodic, post-1900 Ma exhumation of granulites from the deep crust to the surface by $1650 \mathrm{Ma}$ [62]. K-feldspar ${ }^{40} \mathrm{Ar} /{ }^{39} \mathrm{Ar}$ MDD data $\left(\sim 350-150^{\circ} \mathrm{C}\right)$ seamlessly link published high- and low-temperature data and establish rapid cooling and exhumation to the near-surface by $1650-1600 \mathrm{Ma}[55,34]$. Lowtemperature thermochronological studies utilizing $\mathrm{ZHe}$, AFT, and AHe data imply thermal resetting and burial heating of the Athabasca region during the late Proterozoic and again during the early Paleozoic [53, 54, 34]. This sample suite was also recently remodeled (without AFT data) in McDannell and Flowers [34] providing similar results using a different $t-T$ search algorithm and different explicit model boundary conditions. This dataset is the most robust out of all the locations studied due to the greater quantity of high-quality thermochronologic data.

Our QTQt thermal history simulations demonstrate rapid cooling to the surface by $1600 \mathrm{Ma}$, reheating to $\sim 120$ to $<150^{\circ} \mathrm{C}$, followed by cooling to surface again from 750-600 Ma (Fig. 2A-B). Minor reheating en sued during Cambro-Ordovician through Devonian time, in agreement with early deposition in the nearby Western Canada Basin. Geologic constraints are enforced in the model at the timing of presumed cratonic basement exposure prior to Athabasca Basin formation and at the regional basement nonconformity prior to Paleozoic sedimentation (Fig. 2B). A noteworthy outcome is that the integration of multiple Athabasca thermochronometers containing redundant or complementary kinetic information constrain a broad range of $t-T$ space and yield similar model results for both the 'unconstrained' (Fig. 2A) and 'constrained' (Fig. 2B) models (i.e., no constraint boxes compared to the model with constraint boxes). These $t-T$ models suggest $\sim 3-4 \mathrm{~km}$ of exhumation during the Sturtian and Marinoan Snowball glaciations in this intracratonic setting (assuming a $25-35^{\circ} \mathrm{C} \mathrm{km}^{-1}$ paleo-geothermal gradient and $20^{\circ} \mathrm{C}$ surface temperature; used throughout this paper for any exhumation calculations).

\section{Minnesota River Valley Terranes, Southwestern Minnesota, USA}

Minnesota hosts some of the oldest exposed rocks in the United States (Fig. 1), including the $3.5 \mathrm{Ga}$ Morton and Montevideo Gneiss unitsboth of which are intruded by the 2.6 Ga Sacred Heart Granite [68] Paleoarchean Minnesota River Valley Terranes (MRVT) make up the southernmost extension of the Canadian Superior Province and lie west of the 1100 Ma Midcontinent Rift (MCR) (Fig. 1). The late Proterozoic surface history of the SW Minnesota Archean basement is poorly known, however the preserved Sioux Quartzite to the south of the these samples, is a unit that was deposited at ca. 1760-1630 Ma [69]. Regional geologic relationships demonstrate that the Archean crystalline basement was exposed [70] prior to burial during Cambrian through Devonian time, followed by burial again in the Jurassic-Cretaceous [71].

We modelled the ZHe and AHe data reported by Miltich [56] and Guenthner et al. [43]. The QTQt model results (Fig. 2C) suggest cooling ensued ca. 750-650 Ma after maximum heating by ca. $800 \mathrm{Ma}$ that obscures the pre-1000 Ma history. It is conceivable that the reheating that concluded by $800 \mathrm{Ma}$ was due to burial by erosional detritus shed from the nearby Grenville orogenic belt [72]. The Phanerozoic model history is characterized by Cambrian through Devonian reheating, followed by cooling and a second reheating event that peaks in the Cretaceous, both of which agree with the preserved regional geology (also see SI Appendix; Fig. S1). An amphibolite inclusion from the Sacred Heart Granite dated by C. Naeser in 1974 yielded an AFT age of $460 \pm 45$ $\mathrm{Ma}(1 \sigma)[73]$, which is in broad agreement with our Phanerozoic model results showing cooling through the fission-track partial annealing zone $\left(120-60^{\circ} \mathrm{C}\right)$ after $500 \mathrm{Ma}$. These samples are deep in the continental interior and there is no evidence for faulting associated with Rodinia breakup in Minnesota. The effects of 1100 Ma MCR faulting and rifting were localized and would have been followed by thermal subsidence Regardless, all of the MCR events preceded the Cryogenian, thus we anticipate all cooling from $\leq 200^{\circ} \mathrm{C}$ at ca. $720-650 \mathrm{Ma}$ to be associated with $>4 \mathrm{~km}$ exhumation resulting from Cryogenian glacial erosion.

\section{Ozark Plateau, St. Francois Mountains, Missouri, USA}

The Ozarks thermochronology dataset was published by DeLucia et al. [36] and they carried out a combination of forward models to test endmember geologic scenarios under different conditions, as well as inverse $t-T$ models that explained their ZHe data. Individual zircon dates were binned by eU and averaged to create 'synthetic' data for use in the HeFTy software [64]; also see Pikes Peak section below. They interpreted their HeFTy model results as burial due to Rodinia assembly and Grenville orogenesis from 1200-1000 Ma following by significant Neoproterozoic cooling of $\sim 220-200^{\circ} \mathrm{C}$ that they related to the breakup of supercontinent Rodinia. They concluded that exhumation led to increased weathering and $\mathrm{CO}_{2}$ drawdown triggered snowball Earth. Sedimentary burial over the course of the Paleozoic-Mesozoic abruptly ceased with rapid cooling from 225-150 Ma, interpreted as uplift and exhumation from the breakup of supercontinent Pangaea. The Ozark Plateau, like western Colorado (see below), was near the paleo-cratonic margin in the Neoproterozoic-Paleozoic undergoing normal faulting and regional extension $[74,59,57]$. This area hosts extensive structural lineament systems and faults, including the Ste. Genevieve, Cottage Grove, and Rough Creek fault zones, the larger Reelfoot Rift (Fig. 1), and the active New Madrid Seismic Zone [58]. The $\sim 7.5 \mathrm{~km}$ of structural relief that exists between the Great Unconformity exposed in the St. Francois Mtns. and the buried Great Unconformity surface in the adjacent Illinois Basin attests to late Precambrian tectonic deformation [58].

Our QTQt inversions are shown with geologic constraints (Fig. 2D) and the results are broadly consistent with those in DeLucia et al. [36], albeit with a greater number of $t-T$ paths generated during the course of modelling and the use of single-grain $\mathrm{ZHe}$ data. A model without explicit $t-T$ constraints (SI Appendix; Fig. S2) clearly shows that the thermal event that set the AFT data also obscures the sensitivity of the $\mathrm{ZHe}$ data prior to that time. Therefore we used the same modelling conditions as DeLucia et al. [36]. Following ca. 1450 Ma granite emplacement from high temperatures, the geologic constraint at $1365 \pm 15$ Ma and $50 \pm 50^{\circ} \mathrm{C}$ represents cooling of surficial rhyolite or hypabyssal granites to near-surface temperatures (Fig. 2D). The late Cambrian Lamotte sandstone rests unconformably on the Great Unconformity surface and is represented by the constraint box at $560 \pm 75 \mathrm{Ma}$ and $20 \pm 20^{\circ} \mathrm{C}$. We have expanded this $t-T$ box to include Ediacaran time to allow for possible surface exposure prior to sandstone deposition 

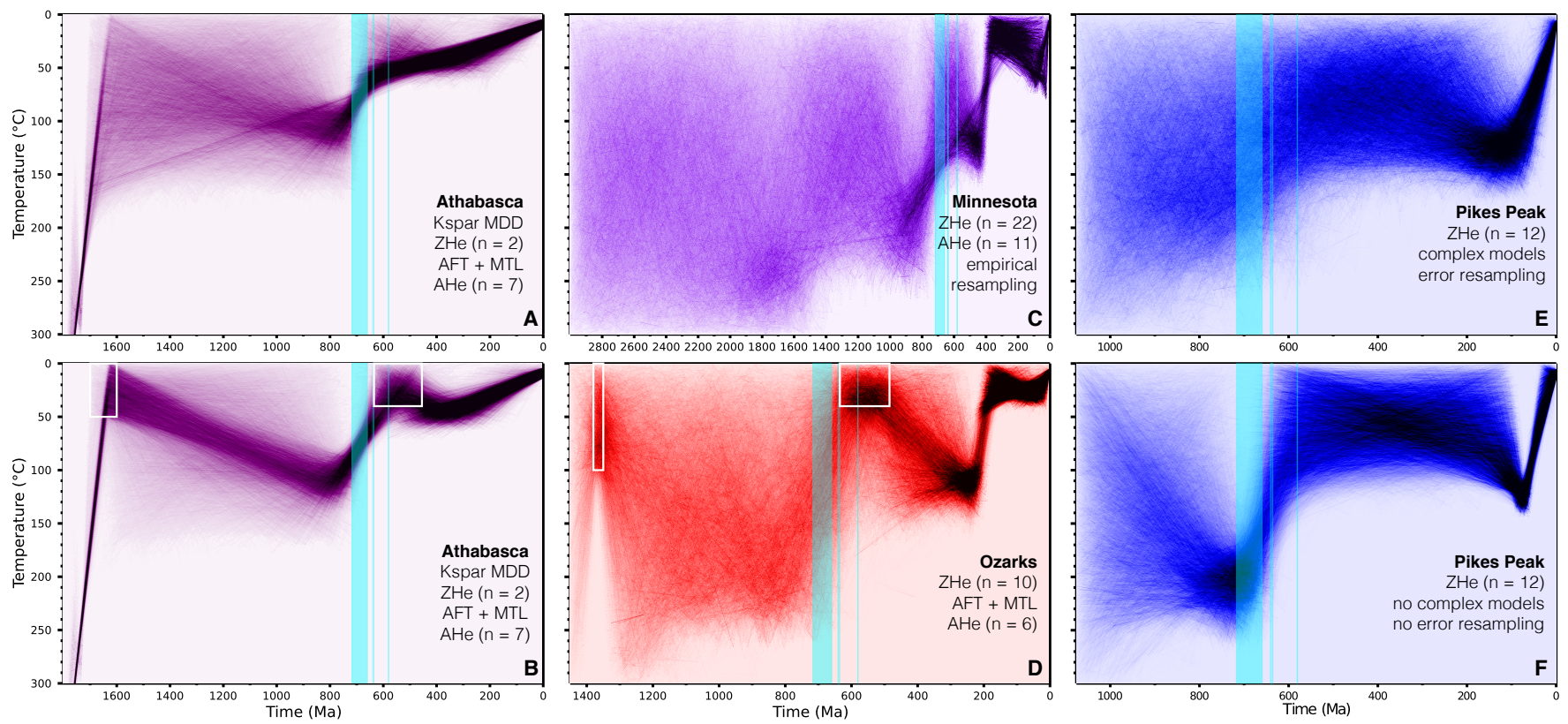

Figure 2: QTQt time-temperature inversions of thermochronology data from North America. Relative probability is proportional to $t-T$ path density, where darker colors (or higher saturation) denotes higher relative probability. Unless otherwise noted on the panels, Hierarchical Bayes 'error resampling' [66, 63] was implemented within QTQt (scaled from 1-100x; with a value of 1 equal to the input uncertainty) and more complex models were accepted for equivalent likelihood (see Materials and Methods for details). Cyan bars are the time intervals for the respective Sturtian, Marinoan, and Gaskiers glaciations and white $t-T$ boxes are geologic constraints. Plots showing observed and predicted data for each simulation are in the Supplementary Information (SI); Figs. S4-S12. (A-B) Inversion results for East Lake Athabasca (Chipman domain) including the K-feldspar ${ }^{40}$ Ar ${ }^{39}$ Ar MDD age spectrum reported by McDannell et al. [55] and (U-Th)/He data reported by Flowers et al. [53] and Flowers [54]. The modeled ZHe dates are from nearby sample 00-196C a few kilometers away. (A) Model without geologic constraints. (B) Model with a constraint box at $1650 \pm 50 \mathrm{Ma}$ between $25 \pm 25^{\circ} \mathrm{C}$, or the time of required basement exposure prior to Athabasca Basin formation [34] and a box at $545 \pm 90 \mathrm{Ma}$ and $20 \pm 20^{\circ} \mathrm{C}$ to include uncertainty in surface exposure prior to Paleozoic burial onset in the adjoining Western Canada Basin. The Sturtian cooling trend is present in both models, with or without boxes. (C) Inversion results without constraint boxes for the Minnesota River Valley terranes data reported by Miltich [56] and Guenthner et al. [43]. A separate model is shown in the SI Appendix; (Fig. S4) implementing geologic constraints of Sioux Quartzite deposition (1695 \pm 65 Ma) and a Precambrian-Cambrian near-surface constraint $(600 \pm 100 \mathrm{Ma})$ prior to Paleozoic burial. The latter box honors the paths at low temperatures in the unconstrained model. The Minnesota ZHe data underwent an empirical form of Hierarchical Bayes resampling (see Materials and Methods and SI Appendix; Fig. S15). (D) Ozarks model result with enforced geologic constraints as described by DeLucia et al. [36], except with an expanded 'Cambrian' box; see text for details. An additional 'no constraint' model is shown in the SI Appendix; Fig. S2. (E-F) Model inversion results for Pikes Peak batholith ZHe data from Flowers et al. [29]. (E) More complex models were allowed and data underwent error resampling, whereas in panel (F) dates were randomly sampled within the assigned $10 \%$ standard deviation and more complex models were only accepted if they improved model predictions with respect to the input ZHe data. Importantly, the Pikes Peak simulations do not incorporate constraint boxes (refer to Fig. 3 below). An alternate model for Pikes Peak is shown in the SI Appendix; Fig. S3.

[75] and to accommodate elevated Cambrian ocean temperatures [76]. The Ozarks ZHe inversion shows reheating between ca. 1300-800 Ma and cooling to surface temperatures by the Cambrian (Fig. 2D). The timing of cooling from peak temperatures of $\sim 250-200^{\circ} \mathrm{C}$ is poorly constrained between ca. 800-650 Ma, albeit still consistent with both 'Rodinia breakup' exhumation and snowball Earth glaciations.

\section{Pikes Peak Batholith, Colorado, USA}

Flowers et al. [29] published a ZHe dataset from the Pikes Peak batholith in Colorado (USA). They modelled 'synthetic' ZHe data (see Ozark Plateau section and SI Appendix for further discussion) collected from samples below the Great Unconformity surface and other fault block locations in their study area. Flowers et al. [29] interpreted their $t-T$ results from this single location as unroofing due to global tectonic activity related to supercontinent Rodinia assembly and/or breakup. While such a model would not be incompatible with a glacial model for the origin of the Great Unconformity, given the tectonic activity of the Pikes Peak region in the Neoproterozoic (as shown by fault-bounded nature of many Tavakaiv bodies; see below), several aspects of their interpretation warrant a critical reexamination. Their [29] $t-T$ modelling hinges on assuming shallow emplacement of the enigmatic Tavakaiv quartzite injectites ${ }^{\dagger}[78,60,79]$ near the

†Flowers et al. [29] maintain that the Tavakaiv injectites contain fragments of Pikes Peak basement that they assert are weathered (i.e., paleosurface at $676 \pm 26 \mathrm{Ma}$ from hematite $(\mathrm{U}-\mathrm{Th}) / \mathrm{He}$ data published by Jensen et al. [80] (Fig. 3A). However, the depth of Tavakaiv emplacement is uncertain due to an unknown emplacement mechanism and the hematite He data can be interpreted as either mineralization or cooling ages [80]. The cooling-age interpretation (our preferred model) requires Neoproterozoic burial reheating [80], which is anticipated near Pikes Peak given the striking similarities between detrital zircon $\mathrm{U}-\mathrm{Pb}$ age distributions for the Tavakaiv dikes and regional Neoproterozoic reference ages [78, 60] (SI Appendix for details). Given the enigmatic nature of Tavakaiv emplacement, their model design could be more accurately described as a compatibility test between the thermochronologic and detrital zircon data; however, the authors presented shallow Tavakaiv emplacement as an a priori constraint and forced their $t-T$ paths to conform to this constraint.

pre-Sturtian) prior to inclusion in the injectite matrix on the basis that the Tavakaiv itself appears "unweathered". However, as a hematitic quartzite, the Tavakaiv is chemically immune to oxidative chemical weathering, so the contrasting weathering extents of the Tavakaiv and the Pikes Peak Granite do not constrain the time of weathering. On the contrary, field relations reveal equivalent degrees of chemical weathering of the susceptible Pikes Peak granite both within and without Tavakaiv dikes (SI Appendix Fig. S13), as part of regional weathering that has long been interpreted as primarily Eocene and later (e.g., Steven et al. [77]). 
Flowers et al. (2020)

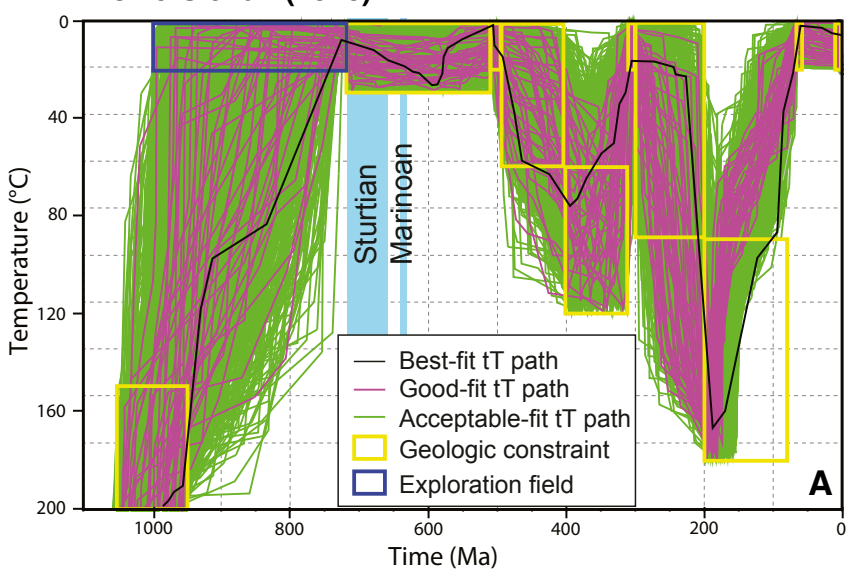

No thermochronology-Boxes only

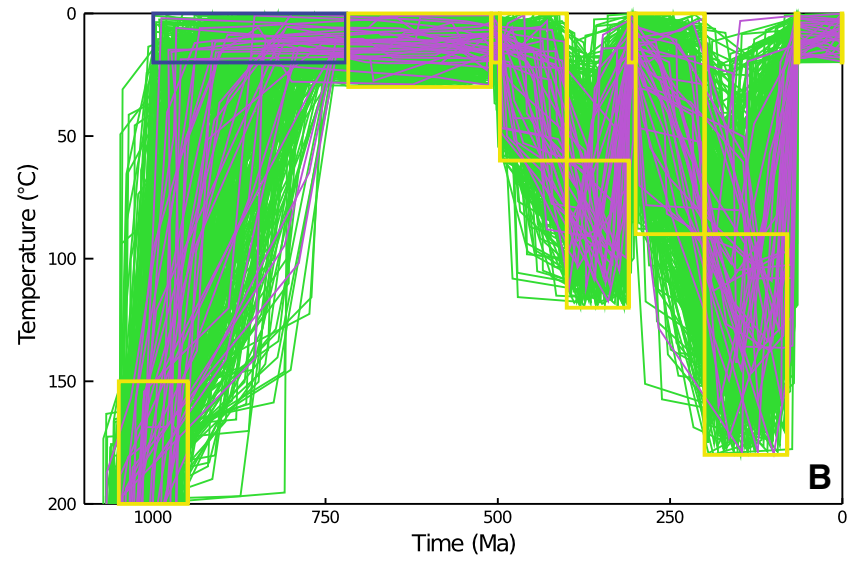

Figure 3: (A) The Flowers et al. [29] HeFTy [64] time-temperature model for Pikes Peak showing constraints used in their modeling (see text and SI Appendix for discussion of the nature of these constraints). (B) Pure Monte Carlo simulations where a simple script was used to generate random paths to pass through constraint boxes without including thermochronologic data. The simulation in (B) shows 500 randomly drawn paths (green) and a subset of 30 paths (purple) randomly drawn from those 500 to more clearly show overall path behavior. Path colors are only meant to resemble the default HeFTy scheme [64]. All boxes are the same as the Flowers et al. [29] model. Our model in (B) only forces path through boxes and is very similar to the Flowers et al. [29] result (their figure 4 or panel A above). It is important to note that their best-fitting paths (in magenta; panel A) are nearly indistinguishable from a random sampling of 30 of our $500 \mathrm{MC}$ paths. A separate model in the SI Appendix; Fig. S14 shows the result of utilizing only the Phanerozoic geologic constraints and the removal of the Precambrian interpretive boxes, also without thermochronology data. Results show that either early cooling to near surface conditions (i.e., a Rodinia tectonic scenario) or late cooling during a Cryogenian glacial cooling scenario are allowed. Figure $2 \mathrm{E}-\mathrm{F}$ shows the results of modelling thermochronology data only (without boxes). The model is truncated at $200^{\circ} \mathrm{C}$ for plotting.

Regardless of the interpretive framework to explain the thermochronology data, the $t-T$ models published by Flowers et al. [29] were largely controlled by their use of 'constraint boxes' in the HeFTy software [64] (Fig. 3A). We verified this by generating random Monte Carlo $t-T$ paths using a simple script that only incorporated their constraint boxes without including thermochronology data (Fig. 3B). In our model (Fig. 3B), random paths were simply forced through the boxes, yielding the same results as Flowers et al. [29]. The box control on modelling is evident from specific placement of their Great Unconformity "exploration field" (Fig. 3A; blue box). This interpretive box (and the other Precambrian boxes) prevent exploration and forced cooling to occur prior to (or by) $720 \mathrm{Ma}$ because paths are required to be between $20-0^{\circ} \mathrm{C}$ from $1000-720 \mathrm{Ma}$ in the model. There is no physical geologic evidence to support a pre-720 Ma surface condition and it is not demanded by the ZHe data (see SI Appendix for details). We ran additional 'no data'
Monte Carlo simulations without Precambrian surface constraints and there are Neoproterozoic cooling paths that satisfy either the glacial or tectonic exhumation hypotheses when not forced to cool to surface temperatures prior to $720 \mathrm{Ma}$ (SI Appendix Fig. S14). The full range of possible $t-T$ paths are also shown after removal of the nested Paleozoic and Mesozoic boxes derived from their assumptions regarding the Pikes Peak history in the Phanerozoic. The example in Figure 2F shows the results of only using the thermochronology data to resolve the thermal history without relying on interpretive $t-T$ boxes.

To better understand the thermal history of the Pikes Peak region, we remodelled the Flowers et al. [29] Pikes Peak ZHe dataset using QTQt. Importantly, we applied no constraint boxes; any variations from uniform path density in the results reflects instead the information contained in the 12 measured single-grain $\mathrm{ZHe}$ dates from their GU surface samples F1936 and F1937 [29]. The resulting $t-T$ history (Fig. $2 \mathrm{E}-\mathrm{F}$ ) exhibits Neoproterozoic cooling from $\sim 220-200^{\circ} \mathrm{C}$ at $\sim 745-700$ Ma to near-surface temperatures by $\sim 660-600 \mathrm{Ma}$. The model in Figure $2 \mathrm{~F}$ is an alternate version where $t-T$ points were only accepted if they resulted in better prediction of the observed dates (i.e., model paths are only as complex as necessary to optimize the data fit between the model and the observations). The latter model provides a lower limit on the complexity required to reproduce the $\mathrm{ZHe}$ data. We prefer to assess the entire stationary distribution of models, however, the maximum likelihood or best-fitting $t-T$ path (not shown; Fig. $2 \mathrm{~F}$ ) exhibits rapid cooling from 659-625 Ma, synchronous with Sturtian deglaciation and the Marinoan glacial interval. It is obvious that the greatest model resolution lies near $200^{\circ} \mathrm{C}$ at ca. $700-660 \mathrm{Ma}$ (constrained by the oldest ZHe grains), followed by cooling to surface before $600 \mathrm{Ma}$, and a late reheating event to $<150^{\circ} \mathrm{C}$ at $<100 \mathrm{Ma}$, presumably due to burial from the Laramide orogeny. Any heating that may have occurred between $600-100 \mathrm{Ma}$ must be $<150^{\circ} \mathrm{C}$ and is not necessarily required or well resolved by the Pikes Peak ZHe data (SI Appendix; Fig. S3). Mid-Paleozoic burial is also not required and basement rocks are not presently mantled by sedimentary cover in the field [29]. The Tavakaiv quartzite injectite emplacement age of $676 \pm 26 \mathrm{Ma}$ from Jensen et al. [80] and the geologic constraint of basement being exhumed to the surface prior to Sawatch sandstone deposition in the Cambrian are honored in our simulation without imposing $t-T$ constraint boxes (Fig. 2E-F). It is possible that faulting, Tavakaiv emplacement, and basement exhumation were coincident near 700-650 Ma due to Rodinia breakup along the cratonic 'margin' and Snowball ice-sheet dynamics (see the $S I$ Appendix for further discussion). The results of our $t-T$ inversion for Pikes Peak basement ZHe data offer support for this scenario while still honoring the interpretation of coeval hematite resetting/cooling and injectite emplacement from $200^{\circ} \mathrm{C}$ to near-surface conditions during the Cryogenian [80]. The Neoproterozoic cooling segment in our model is consistent with both the Sturtian and Marinoan glaciations and Rodinia breakup resulting in up to $\sim 5-7 \mathrm{~km}$ of erosional exhumation.

\section{RECONCILING NEOPROTEROZOIC EXHUMATION TRENDS}

\section{Spatial patterns of tectonic and glacial erosion of continents}

McDannell et al. [55] and DeLucia et al. [36] came to the conclusion that kilometer-scale Neoproterozoic exhumation occurred after $1 \mathrm{Ga}$ within the North American interior and linked this to formation of the Great Unconformity due to Rodinian geodynamics and/or snowball Earth glaciations. These two hypotheses are not mutually exclusive-it is possible that both tectonics and glaciation contributed to global Earth system disruption [81, 82] during formation of the Great Unconformity. Glaciation would be most effective as a driver of erosion in regions with preexisting topography (be it from rifting or orogeny), therefore erosional synergy between tectonics and ice sheets is a possibility [e.g., 83]. Ultimately with respect to the Great Unconformity, it may be that the generally accepted reconstruction(s) of more concentrated 
equatorial packing of the Rodinian continents [11, 84], along with the unique environmental conditions of the Neoproterozoic, proved to be a time of geologic serendipity unlike most any other in Earth history.

Direct and meaningful comparisons between tectonic and glacial unconformity hypotheses are complicated by the fact that there are precise estimates for the timing of Snowball glaciations [23], whereas the timing and duration of Rodinia assembly and breakup remain incompletely understood due to discrepancies between paleomagnetic and geologic data [e.g., 85, 11, 84]. Rodinia assembly and breakup occurred episodically and diachronously over at least 250 million years for each phase with timing dependent upon location [10,11]. Invocation of Rodinian tectonics as a primary, global cause of the Great Unconformity partly requires a consensus or at least reconciliation of the myriad configurations of the supercontinent [e.g., 86, 74, 87, 11, 88, 84, 89] to construct valid geodynamic models of uplift during the supercontinent cycle. Otherwise, any thermochronologic cooling signal can simply be attributed to "Rodinian tectonics" in the Neoproterozoic. Notwithstanding Rodinia's exact arrangement, the majority of rift-related deformation and exhumation would have been confined to cratonic margins or to localized horst-graben systems [e.g., 90]. A question that arises by appealing to 'tectonics' as a global cause of the Great Unconformity is: why do we not observe an equivalent hiatus as a result of the assembly and breakup of other supercontinents such as Pangaea? If supercontinent cyclicity caused global unconformities akin to the Great Unconformity, we anticipate that the North American Sauk Sequence (as currently defined) would instead occur in the late Mesozoic due to capture by Pangaean erosion. The lull in Pangaean sediment volume [8] during supercontinent breakup is instead due to sea-level low stand during an interval of non-deposition - and is not the same stepwise difference in sediment volume that occurs prior to the beginning of the Phanerozoic [5].

The dynamics of supercontinent breakup remain poorly understood [91], yet we focus on discussion of this here, since the timing of rifting in North America most closely overlaps with Snowball glaciations and the timing of cooling in our $t-T$ inversions. Mantle-plume push (i.e., 'bottom-up' processes; 92) and plate boundary dynamics (i.e., subduction retreat or 'top-down' processes; 93) both govern supercontinent breakup [94, 91]. Mantle plumes initiate breakup [95], as evidenced by large igneous province eruptions that are either the cause or manifestation of supercontinent demise [91]. Successful rifting results in a passive margin and the high number of passive margins during staged Rodinia disassembly [96] implicate Laurentian margin rifting as the dominant mode and locus of tectonic activity during the Neoproterozoic. Longstanding models suggest supercontinents insulate the mantle causing upwelling and breakup [e.g., 97], however recent work suggests that subduction plays the dominant role in subcontinental mantle upwellings [98]. Laurentia would not have well established margin subduction zones until ca. 600-540 Ma [99], which broadly explain the formation (i.e., subduction-related dynamic topography) of North American cratonic unconformities [100] in the Phanerozoic [101] —leaving early Neoproterozoic continental dynamics an open question.

A dynamic topographic response to mantle convection anomalies can produce low amplitude surface uplift [e.g., 102], tilting, and erosion across a continental interior over a few million years [e.g., 103], although this often involves a complex interplay between plate motions and mantle swell position, topography and drainage network organization, and climate change [104]—which are exceedingly difficult to quantify in the Proterozoic. The erosional response to dynamic uplift is proportional to the upwelling wavelength [105]; therefore dynamic topography would be required at the scale of the North American continent to induce widespread erosion that agrees with our models. Continental erosion would likely be limited within the interior $(<1-3 \mathrm{~km})$ and occur relatively slowly over many tens of Myr [e.g., 103, 106] in the absence of significant modification of the cratonic lithosphere [e.g.,
55]. This is considerably less than the amount of unroofing suggested by our $t-T$ models. However speculative, an episode of widespread kilometer-scale epeirogenic uplift associated with a thermally buoyant Rodinia supercontinent $[107,108]$ may have led to increased continental exposure and the formation of the Great Unconformity on multiple continents. Erosional detritus would have in turn influenced ocean chemistry and atmospheric $\mathrm{CO}_{2}$ concentrations that contributed to snowball Earth glaciations [109, 110, 111, 22].

Conversely, Snowball glaciations could have been the main driver of erosion that created the Great Unconformity. Through a combination of wet-based glacial sliding and lowering of erosional base level, global glaciations in the late Neoproterozoic could have removed several kilometers of rock (including cratonic sedimentary rocks) to produce the Great Unconformity surface. Notably, this would not require incision rates any different than those observed in modern ice-sheet environments. A scenario where modest continental ice sheet incision rates are effectively constant at 0.05 to $0.1 \mathrm{~km} \mathrm{Myr}^{-1}$ yields $2.9-5.8 \mathrm{~km}$ of exhumation over the Sturtian glacial interval alone. Large amounts of exhumation could be accomplished at either lower rates for prolonged periods of basal ice sliding or more rapidly over short intervals during deglaciation. For example, Cowton et al. [112] indicated that the modern Greenland ice sheet erosion rate is $\sim 2.2-7.4 \mathrm{~km} \mathrm{Myr}^{-1}$ (from the ice margin to $>50 \mathrm{~km}$ inland) during the deglacial phase, which is at least an order of magnitude higher than previously established ice sheet erosion rate estimates [113], and places incision rates on par with empirical estimates of $\sim 1$ to $>10 \mathrm{~km} \mathrm{Myr}^{-1}$ for temperate glaciers [114]. The results of Neoproterozoic ice-sheet simulations demonstrate that only high-latitude Rodinian cratons (i.e., not Laurentia) would have been characterized by cold-based ice; with low-latitude interior basal ice temperatures near $0^{\circ} \mathrm{C}$ and continental basal sliding displacement rates of $\sim 1$ to $>10 \mathrm{~m} \mathrm{yr}^{-1}$ [33]. Furthermore, glacial incision is expected to increase with decreasing latitude [114] and the low-latitude position of Rodinia during the late Neoproterozoic favored increased continental weatherability and precipitation rates [115], thus creating a relationship where erosion would be maximized with lubricated basal ice increasing sliding_-leading to more rapid erosion [116].

Cratonic interiors provide the only location to truly test and differentiate the hypotheses of pre-, syn-, or post-Cryogenian formation of the Great Unconformity. Timing is a critical component of this signal, but spatial pattern and magnitude of exhumational rock cooling are also important. Tectonic rifting and glacial erosion will produce opposing spatial patterns of exhumation and different magnitudes of crustal unroofing across a continent. The majority of exhumation associated with supercontinent assembly and breakup would be limited to compressional orogenic belts and extensional (faulted) rift margins, respectively. Rifting will see large exhumation narrowly restricted to continental margins, where tectonic activity is highest, whereas stable continental interiors will experience little to no erosion or even deposition. In addition to orogenic erosion, intraplate stresses manifest as continental extension [e.g., 59], causing subsidence and burial across a craton $[117,118,119]$. This is hypothesized for the Rodinian interior during terminal assembly and incipient breakup [e.g., 72] and agrees with the consistent heating signal seen in our thermochronological inversions (Fig. 2). We would expect most tectonic uplift and erosion to occur during early supercontinent assembly and orogenesis, rather than breakup. Thus the rock-cooling signals for Rodinia assembly (ca. 1300-900 Ma; 11), major rift breakup phases (ca. 850-680 Ma; 12, 99), and snowball Earth glaciations (ca. 720-635 Ma) should be rather distinct in terms of timing and location. As an example, recent work by Ricketts et al. [31] apparently shows exhumation that broadly aligns with exhumation during Rodinia assembly in the southwestern USA. While they did not jointly invert ${ }^{40} \mathrm{Ar} /{ }^{39} \mathrm{Ar}$ and zircon (U-Th)/He data, early or episodic Neoproterozoic exhumation may nevertheless be expected locally, since western North America was undergoing active tectonism during that time [e.g., 59]. 
In contrast, long-term glacial erosion will produce high-magnitude exhumation over areas of $1000 \mathrm{~s}$ of $\mathrm{km}^{2}$, with ice sheet margins either experiencing very little or extremely high incision due to fluctuating ice dynamics and runoff [33, 109]. The timing of cooling in our models is coincident with both rifting and glaciation in western North America We would expect the tectonic versus glacial signals of exhumation on a paleo-cratonic margin (or at least areas experiencing Rodinian syn-rift breakup deformation), to be nearly indistinguishable from one anotheras observed in the Pikes Peak region. Locations such as Athabasca are too far from continental margins to have experienced $>3 \mathrm{~km}$ of erosion over a short interval solely due to rifting. Moreover, if there is widespread erosion during a 'hard snowball' glaciation, ice would have to be a dominant erosive agent. The only foreseeable way to obtain a consistent, high-magnitude, and synchronous Cryogenian unroofing signal at the continental scale is through ice-sheet glaciation. Our $t-T$ model results demonstrate the viability of such an exhumation pattern across North America.

\section{Deep continental ice-sheet erosion}

Widespread, deep Neoproterozoic glacial erosion [120] may be met with skepticism because of the often held perception that continental ice sheets cannot deeply erode the upper crust [e.g., 121, 122]. Early estimates of physical erosion as a result of the Laurentide glacial episode were that $\sim 120 \mathrm{~m}$ of rock was removed over the last 3 Myr across upper North America [123]. In the absence of dramatic changes to continental freeboard this is reasonable because sediments are essentially eroded and redeposited repeatedly, cutting down to the same base level-leaving the pre-glacial crystalline basement surface mostly intact. Laurentide glaciation is however not an analog to Cryogenian glaciations, since continental freeboard was fundamentally different (i.e., lower) during the Cryogenian and is essential for deep glacial incision [5]. Net base-level fall during snowball Earth termination (and shortly after glaciation) are predicted to be the greatest (up to $-600 \mathrm{~m}$ ) in continental interiors, and decrease towards margins [22], whereas proxy reconstructions and glacial ice models suggest less than $-120 \mathrm{~m}$ relative sea-level fall during the Laurentide [124]. The Laurentide ice divide was positioned over the Hudson Bay Basin where preservation of sedimentary strata was likely due to low rates of basal sliding at the thickest portion of the ice sheet [125], which suggests that there have been no drastic glacio-isostatic changes to continental freeboard since the Neoproterozoic to cause complete removal of this succession. The simple observation that the thickest parts of the Laurentide ice sheet [e.g., 126] match the currently exposed extent of the Canadian Shield implies that any continental ice sheet is capable of denuding the craton.

Within the context of the Great Unconformity, nearly the entire Proterozoic ( $>25 \%$ of Earth history) would have been a time of net sediment accumulation - and the Snowball glacials would have removed the thickest rock column, when compared to any event that followed (i.e., later erosion would have inherently removed less material). An underappreciated aspect of the 'deep erosion' argument is that continental-scale exhumation need not imply that most of the crust removed was crystalline basement; on the contrary, a substantial portion of the eroded crust may well have been intracratonic sedimentary rocks deposited during the Proterozoic across the continental interior [e.g., 127, 72] Geology and our inversions directly indicate burial heating of basement was probably due to thick Proterozoic cover for (at least) the Athabasca region and the Ozark Plateau. In support of this, global average zircon ${ }^{176 / 177} \mathrm{Hf}$ and $\delta^{18} \mathrm{O}$ isotope anomalies were interpreted as old crustal material from the Earth's surface being subducted and incorporated into new magmas in the Neoproterozoic [5]. The $\mathrm{Hf}$ and ${ }^{18} \mathrm{O}$ isotopic signatures only require surface exposure and subduction of crust containing ancient zircons-whether that material was directly sourced from Precambrian basement or recycled from Proterozoic basins makes little difference. Ocean basins serve as the main repository for sediments produced during ice-sheet denudation [120, 123], and due to the shorter oceanic crust lifecycle (compared to continental crust), provide one explanation for the reduced survival rate of Proterozoic detritus that is evident in the Ronov et al. [9] compilations. This conceptually agrees well with the observation that many Archean and Proterozoic terranes have experienced relatively modest amounts of secular (isostatic) crustal erosion [128], that Neoproterozoic sediment supply and subduction were critical for kickstarting the modern plate tectonic regime [129], partially explains the variability or apparent lack of evidence for snowball Earth glacial incision [130], and agrees with time-averaged measurements of net continental exhumation rates that approach zero over gigayear timescales [131].

\section{THERMOCHRONOLOGIC SUPPORT FOR A GLACIAL UNCONFORMITY}

The anomalous abundance of unconformities near the ProterozoicPhanerozoic boundary, each one different, and frequently composite, but evidently captured by a globally widespread erosive event are what make the Great Unconformity unique. Neoproterozoic glacial erosion that we interpret as the primary cause of the Great Unconformity, is detected in North American thermochronometry without making numerous assumptions about past conditions. We stress that assumptions about past geologic conditions should not be prescribed as evident, or imposed in lieu of quantitative thermochronology in thermal-history models. Our thermochronological inversions honor the measured isotopic data and physical geology, while demonstrating that the late Proterozoic basement nonconformity is a feature that: $(i)$ manifests as large-magnitude erosion between ca. 700-635 Ma, (ii) maintains consistency across North America for multiple locations over a thousand kilometers, and (iii) can be interpreted as widespread (albeit likely spatially heterogeneous) erosional unroofing of at least $3-5 \mathrm{~km}$. Collectively these features can only be readily satisfied by a Cryogenian glacial model for exhumation of rocks sampled from both proximal and distal reaches of exposed Laurentian cratonic basement. It is important to note that this major denudation event does not preclude later, minor sub-kilometer scale erosion (or non-deposition) that undoubtedly occurred across the craton prior to Cambrian flooding of the continent. The removal of $\sim 3-5 \mathrm{~km}$ of thick Mesoproterozoic basin rocks and upper crust from the craton likely caused a disturbance to the stable crustal thermal structure-leaving it warm and isostatically buoyant; thereby inhibiting extensive deposition until Paleozoic transgressions during Pannotia-Gondwana plate reorganization [e.g., 132].

Development of the Great Unconformity as a physical surface is only constrained in this work between the Cryogenian erosion pulse observed in our $t-T$ models and the age of the overlying sediments- therefore, we do not rule out a multi-stage or multi-process model for the individual unconformity surfaces associated with the Great Unconformity as a broader phenomenon. However, in order to create and subsequently preserve a widespread unconformity by aggradation, most topographic relief must be removed and the landscape needs to be at (or below) base-level [i.e., 6] - which is difficult to achieve by fluvial or hillslope processes alone. It may be that continental-scale glaciation is the only foreseeable process that can account for both the formation and preservation of the Great Unconformity. Major unconformities, or significant step-changes in North American (or global) sediment abundance are not observed during other times of equatorial continental assembly, potentially invalidating supercontinent tectonic activity as the primary or sole driver of Neoproterozoic exhumation. In our view, it is not a coincidence that the thermochronologic inversions shown here demonstrate nearly synchronous exhumation transpiring across a vast region of North America during a known period of apparent worldwide glaciation. We present a more comprehensive appraisal for the origin of the Great Unconformity within North America that serves as a template for assessing exhumation globally to necessarily test further 
the hypothesis of a glacial origin due to snowball Earth conditions in the Neoproterozoic.

\section{Materials and Methods}

Inverse $t-T$ simulations are presented for samples from the North American interior and were modeled using the QTQt v. 5.8.0 software [63] The QTQt program utilizes Bayesian statistics and a reversible jump Markov chain Monte Carlo (rjMCMC) search method. We modelled $\mathrm{K}$-feldspar ${ }^{40} \mathrm{Ar} /{ }^{39} \mathrm{Ar}$, zircon (U-Th)/He (ZHe), apatite fission-track (AFT), and apatite (U-Th)/He (AHe) data, implementing the multidiffusion domain (MDD) model of Lovera et al. [39], zircon radiation damage accumulation and annealing model (ZRDAAM) of Guenthner et al. [43], the AFT multikinetic annealing model of Ketcham et al. [133], and the AHe radiation damage (RDAAM) kinetic model of Flowers et al. [42] for each respective thermochronometer in our surveyed datasets. To encourage thorough exploration of $t-T$ space, more complex models were accepted for equivalent likelihood and proposal jumps were rejected if they were proposed outside of the general prior ( $t-T$ model space) in QTQt. A total of 1,000,000 models were completed for each example, with 500,000 burn-in iterations that were discarded and an additional 500,000 iterations retained post burn-in for each simulation. The acceptance rates were within the recommended range of $0.1-0.6$ and the sampling distribution reached stationarity under these conditions, which collectively signify model convergence [63].

\section{Quantification of data uncertainties}

Currently, uncertainties related to eU estimation [e.g., 134], U-Th isotopic zonation [e.g., 135, 136], and imperfect grain geometries are not easily or routinely characterized, therefore it is reasonable to assume that single-grain date uncertainties at the $2 \sigma$ level are underestimated for both zircon and apatite (U-Th)/He thermochronometry. It is customary for analytical errors to be calculated from the propagated uncertainty from $\mathrm{U}, \mathrm{Th}$, and He measurements. Uncertainties are on the order of $\sim 1-5 \%$, and typically about 2-3\% [137]. However, the uncertainties including the Ft correction for alpha ejection are commonly greater, and the reproducibility of laboratory age standards yields total uncertainties nearer to $8-10 \%$ for zircon and $\sim 6-7 \%$ for apatite [137]. These error estimates are more realistic, yet still conservative, and correspond to two standard deviations typically observed on replicate single-grain laboratory age standard Fish Canyon Tuff zircon and Durango apatite analyses [e.g., 138, 137, 134]. The age reproducibility estimated for large numbers of replicate analyses of natural AHe samples is much worse, on the order of 15-20\% or more [e.g., 139]. We usually applied $6 \%$ uncertainty for AHe dates (typical Durango apatite reproducibility) and $8-10 \%$ for $\mathrm{ZHe}$ dates [137] if reported uncertainties were less than these values before modelling. During modelling, dates were randomly sampled from a normal distribution centered on the reported/assigned error (scaled from 1 to $100 \mathrm{x}$ the input error), which we refer to as 'error resampling', a form of Hierarchical Bayes resampling utilized in QTQt where the data are used directly for uncertainty inference and the variance of the data errors are estimated from their most probable value, given the data $[66,63]$.

There are often additional, unexplained sources of geological age dispersion that are not captured by the calculated He date uncertainties. For example, $\mathrm{ZHe}$ grains of the same size and eU content that experienced the same thermal history should hypothetically yield the same date, but this is often not observed in practice. Error resampling is helpful when errors are underestimated and prevents the search algorithm from becoming trapped in local minima by reducing overprecision. If the data uncertainties are uniformly overprecise, then error resampling will generally aid the rjMCMC search while improving $t-T$ resolution, whereas if the data quality is heterogeneous (e.g., inexplicably old, overdispersed AHe dates) there may be difficulty in reconciling predicted and observed data. In scenarios where there are abundant, dispersed data of varying quality (i.e., Minnesota dataset), another type of Empirical Bayes resampling was utilized to explore ZHe date uncertainties. The aim was to expand uncertainty accounting where the prior hyperparameters (i.e., observed dates) will have a prior distribution that expresses their initial uncertainty and a posterior distribution that is determined by the data directly [66]. The individual date errors were treated as hyperparameters drawn from a probability distribution and the data variance was used to infer date uncertainty. Importantly, observed dates were modeled but the weighted uncertainty was inferred from the scatter of the data as determined by the standard deviation of the data weighted by a Gaussian kernel in eU space $(\sigma \mathrm{eU}=100 \mathrm{ppm})$. The empirical Bayes resampling code is available as a Jupyter notebook from https://github.com/kmcdannell/helium-empirical-bayes.git.

\section{Athabasca}

We modelled the K-feldspar MDD sample 02-123A from McDannell et al. [55]. Refer to McDannell and Flowers [34] for further information on sample data. QTQt modelling information: general prior $(t-T$ model space) $900 \pm 900 \mathrm{Ma}$ and $200 \pm 200^{\circ} \mathrm{C}$ with an imposed $10^{\circ} \mathrm{C} / \mathrm{Myr}$ maximum heating/cooling rate. Model truncated at $300^{\circ} \mathrm{C}$ for plotting purposes.

\section{Minnesota}

We modelled the $\mathrm{ZHe}$ and AHe samples contained primarily in the Miltich thesis [56] and Guenthner et al. [43]. The Minnesota ZHe samples underwent Empirical Bayes resampling due to the greater number of scattered $\mathrm{ZHe}(\mathrm{n}=22)$ dates and the extreme timescale involved in modelling $(\sim 2-3 \mathrm{x}$ other examples). The majority of reported MRVT (U-Th)/He dates ranged from ca. 925-10 Ma (zircon) and ca. 1725-125 Ma (apatite) [56]. Extreme age overdispersion of over $1 \mathrm{Ga}$ affected the apatite grains, which were noted as poor quality by Miltich [56]. We refrained from modelling the oldest uncorrected dates because they were typically characterized by very small grain sizes ( 30-40 micron halfwidths) and were much older than the more numerous ca. 300-200 Ma grains. Most raw (no Ft correction) $\mathrm{AHe}$ dates ranged from about $270 \pm 90 \mathrm{Ma}$ over a range of $37 \pm 34 \mathrm{ppm}$ eU. We conservatively applied $10 \%$ errors to the MRVT apatites $(n=11$ of 16 total analyses) due to the questionable quality of the data-but did not utilize hierarchical error resampling since the dataset likely contains both representative and extreme outlier ages. In this case, error resampling would incorrectly treat all observed dates as reliable, yet more uncertain than initially quantified. The oldest dates were excluded as clear outliers because they were much older than the mean age and during simulation trials they were among the highest misfit grains in the inversions (i.e., grains older than $\sim 400 \mathrm{Ma}$ were instead always predicted between ca. 200-350 Ma). The remaining dates form a positive date-eU trend that 'plateaus' at high eU and generally aligns with the RDAAM expectations. QTQt modelling information: general prior $\left(t-T\right.$ model space) $1500 \pm 1500 \mathrm{Ma}$ and $150 \pm 150^{\circ} \mathrm{C}$ with an imposed $5^{\circ} \mathrm{C} / \mathrm{Myr}$ maximum heating/cooling rate. Constraint boxes represent Sioux Quartzite deposition at $1695 \pm 65 \mathrm{Ma}$ and $40 \pm 40^{\circ} \mathrm{C}$ and late Precambrian basement exposure $25 \pm 25^{\circ} \mathrm{C}$ prior to late Cambrian Mt. Simon sandstone deposition $(600 \pm 100 \mathrm{Ma}$; the unconstrained MRVT model shows solutions at near-surface temperatures during this entire interval; supporting box placement).

\section{Ozarks}

We remodeled ZHe (samples 14OZ01 and 14OZ11; $n=10$ ), AFT (sample 14OZ07), and AHe data (sample 14OZ11; $n=6$ ) collected from basement below the Great Unconformity surface in the St. Francois Mountains of Missouri from DeLucia et al. [36]. The ZHe samples that 
provided the broadest range in dates and $\mathrm{eU}$ were chosen for modelling ( $\sim 1050-180 \mathrm{Ma}$ and $\sim 400-1800 \mathrm{ppm} \mathrm{eU})$. The dates from the other samples cluster around $\sim 700-600 \mathrm{Ma}$. The AFT sample central age is $185 \pm 16 \mathrm{Ma}(\mathrm{n}=20)$ and mean track length is $13.54 \pm 1.23 \mu \mathrm{m}$ $(\mathrm{n}=78)$ with a mean Dpar (track etch pit diameter) of $1.75 \mu \mathrm{m}$. The AHe sample contains 6 grains $(<15 \mathrm{ppm}$ eU) with dates between $\sim 210-150 \mathrm{Ma}$. This information alone signifies heating to temperatures $>100-120^{\circ} \mathrm{C}$ near $200 \mathrm{Ma}$ to cause thermal resetting of the AFT system followed by relatively rapid cooling through $\sim 110-60^{\circ} \mathrm{C}$. QTQt modelling information: general prior ( $t-T$ model space) $725 \pm 725 \mathrm{Ma}$ and $150 \pm 150^{\circ} \mathrm{C}$ with an imposed $5^{\circ} \mathrm{C} / \mathrm{Myr}$ maximum heating/cooling rate. Error resampling (1-100x) for ZHe data and complex models allowed for both scenarios.

\section{Pikes Peak}

We remodelled zircon (U-Th)/He data from Pikes Peak samples F1936 and F1937 collected from Great Unconformity surfaces reported by Flowers et al. [29]. The 12 single-grain dates span between $\sim 1000-45$ Ma and 30-2000 ppm eU. QTQt modelling information: general prior $\left(t-T\right.$ model space) $538 \pm 538 \mathrm{Ma}$ and $150 \pm 150^{\circ} \mathrm{C}$ with an imposed maximum heating/cooling rate of $5^{\circ} \mathrm{C} / \mathrm{Myr}$. Error resampling (1-100x) for $\mathrm{ZHe}$ data and more complex models allowed for Fig. 2E. The Fig. $2 \mathrm{~F}$ model did not undergo error resampling and more complex models were rejected for equivalent likelihood values. Therefore, proposed $t-T$ paths were only accepted if they provided a better fit to the data.

\section{ACKNOWLEDGEMENTS}

This work was supported by the NSF Division of Earth Sciences Sedimentary Geo \& Paleobiology program awards 2044800 to C.B.K. and K.T.M., 2044603 to P.K.Z., and 2044907 to W.R.G. The Government of Canada Geo-mapping for Energy and Minerals (GEM) Program is recognized by K.T.M. for support during development of these ideas. D.L.S. ac knowledges support of the Ann and Gordon Getty Foundation. Thanks to K. Gallagher for QTQt code updates. K. Dewing is thanked for comments on an earlier version of this manuscript

\section{Author Contributions}

Contributor Roles Taxonomy (CRediT) author statement. KTM: conceptualization, methodology, formal analysis, software, investigation, visualization, interpretation, funding acquisition, project administration, writing-original draft; $\mathrm{CBK}$ : conceptualization, methodology, software, writing-original draft, interpretation, funding acquisition, project administration; WRG: validation, funding acquisition, project administration; PKZ: writing-editing, validation, funding acquisition, project administration; DLS: validation, conceptualization.

\section{REFERENCES}

[1] George Halcott Chadwick. Subdivision of geologic time. Bulletin of the Geological Society of America, 41:47-48, 1930.

[2] Charles D Walcott. Cambrian Geology and Paleontology, volume 57 of Smithsonian Miscellaneous Collections. The Lord Baltimore Press, 11914.

[3] Clarence Edward Dutton. Tertiary History of the Grand Cañon District, with Atlas. Monographs of the United States Geological Survey, 2:1-264, 1882.

[4] Shanan E Peters and Robert R Gaines. Formation of the 'Great Unconformity' as a trigger for the Cambrian explosion. Nature, 484(7394):363-366, 2012.

[5] C Brenhin Keller, Jon M Husson, Ross N Mitchell, William F Bottke, Thomas M Gernon, Patrick Boehnke, Elizabeth A Bell, Nicholas L Swanson-Hysell, and Shanan E Peters. Neoproterozoic glacial origin of the Great Unconformity. Proceedings of the National Academy of Sciences, 116(4):1136-1145, 2019. doi: 10.1073/pnas.1804350116.

[6] Harry E. Wheeler. Baselevel, lithosphere surface, and timestratigraphy. Bulletin of the Geological Society of America, 75(7):599-610, 1964. ISSN 19432674. doi: 10.1130/ 0016-7606(1964)75[599:BLSAT]2.0.CO;2.

[7] Alexander B Ronov, V Ye Khain, A N Balukhovskiy, and K B Seslavinskiy. Changes in distribution, volumes, and rates of deposition of sedimentary and volcanogenic deposits during the Phanerozoic (within the present continents). International Geology Review, 19(11):1297-1304, 1977.

[8] A. B. Ronov, V. E. Khain, A. N. Balukhovsky, and K. B. Seslavinsky. Quantitative analysis of Phanerozoic sedimentation. Sedimentary Geology, 25(4):311-325, 1980. ISSN 00370738. doi: 10.1016/0037-0738(80)90067-6.

[9] A. B. Ronov. The Earth's Sedimentary Shell (Quantitative Patterns of its Structure, Compositions, and Evolution): The 20th V.1. Vernadskiy Lecture, March 12,1978. International Geology Review, 24(11):1313-1363, 1982. ISSN 19382839. doi: $10.1080 / 00206818209451075$

[10] Joseph G Meert and Trond H Torsvik. The making and unmaking of a supercontinent: Rodinia revisited. Tectonophysics, 375(1-4): 261-288, 2003.

[11] Zheng-Xiang Li, S V Bogdanova, A S Collins, Anthony Davidson, Bert De Waele, R E Ernst, I C W Fitzsimons, R A Fuck, D P Gladkochub, and J Jacobs. Assembly, configuration, and break-up history of Rodinia: a synthesis. Precambrian Research, 160(1):179-210, 2008

[12] Zheng-Xiang Li, David A D Evans, and Galen P Halverson. Neoproterozoic glaciations in a revised global palaeogeography from the breakup of Rodinia to the assembly of Gondwanaland. Sedimentary Geology, 294:219-232, 2013.

[13] Devon B. Cole, Daniel B. Mills, Douglas H. Erwin, Erik A. Sperling, Susannah M. Porter, Christopher T. Reinhard, and Noah J. Planavsky. On the co-evolution of surface oxygen levels and animals. Geobiology, 18(3):260-281, 2020. doi: 10.1111/gbi.12382.

[14] James C G Walker, P B Hays, and James F Kasting. A negative feedback mechanism for the long-term stabilization of Earth's surface temperature. Journal of Geophysical Research: Oceans, 86(C10):9776-9782, 1981.

[15] Paul F Hoffman, Alan J Kaufman, Galen P Halverson, and Daniel P Schrag. A Neoproterozoic Snowball Earth. Science, 281 (5381):1342-1346, 1998. doi: 10.1126/science.281.5381.1342.

[16] Paul F Hoffman and Daniel P Schrag. The snowball Earth hypothesis: testing the limits of global change. Terra Nova, 14 (3):129-155, 2002.

[17] Lawrence M Och and Graham A Shields-Zhou. The Neoproterozoic oxygenation event: Environmental perturbations and biogeochemical cycling. Earth-Science Reviews, 110(1-4):26$57,2012$.

[18] Andrew H Knoll. The geological consequences of evolution. Geobiology, 1(1):3-14, 2003. doi: 10.1046/j.1472-4669.2003. 00002.x.

[19] Adam C Maloof, Susannah M Porter, John L Moore, Frank O Dudas, Samuel A Bowring, John A Higgins, David A Fike, and Michael P Eddy. The earliest Cambrian record of animals and ocean geochemical change. Geological Society of America Bulletin, 122(11-12):1731-1774, 2010.

[20] Erik A. Sperling, Christina A. Frieder, Akkur V. Raman, Peter R. Girguis, Lisa A. Levin, and Andrew H. Knoll. Oxygen, ecology, 
and the Cambrian radiation of animals. Proceedings of the National Academy of Sciences of the United States of America, 110(33):13446-13451, 8 2013. ISSN 00278424. doi: 10.1073/ pnas. 1312778110 .

[21] J L Kirschvink. Late Proterozoic low-latitude global glaciation: the snowball Earth. In The Proterozoic Biosphere, volume 52, pages 51-52. Cambridge University Press, 1992. ISBN 9780521366151.

[22] Paul F Hoffman, Dorian S Abbot, Yosef Ashkenazy, Douglas I Benn, Jochen J Brocks, Phoebe A Cohen, Grant M Cox, Jessica R Creveling, Yannick Donnadieu, and Douglas H Erwin. Snowball Earth climate dynamics and Cryogenian geologygeobiology. Science Advances, 3(11):e1600983, 2017.

[23] Alan D. Rooney, Justin V. Strauss, Alan D. Brandon, and Francis A. Macdonald. A Cryogenian chronology: Two long-lasting synchronous Neoproterozoic glaciations. Geology, 43(5):459462, 2015. ISSN 19432682. doi: 10.1130/G36511.1.

[24] Anthony R Prave, Daniel J Condon, Karl Heinz Hoffmann, Simon Tapster, and Anthony E Fallick. Duration and nature of the end-Cryogenian (Marinoan) glaciation. Geology, 44(8):631-634, 2016.

[25] Eli Tziperman, Itay Halevy, David T Johnston, Andrew H Knoll, and Daniel P Schrag. Biologically induced initiation of Neoproterozoic snowball-Earth events. Proceedings of the National Academy of Sciences, 108(37):15091-15096, 2011.

[26] Grant M Cox, Galen P Halverson, André Poirier, Daniel Le Heron, Justin V Strauss, and Ross Stevenson. A model for Cryogenian iron formation. Earth and Planetary Science Letters, 433:280-292, 2016.

[27] Francis Alexander Macdonald and Robin Wordsworth. Initiation of Snowball Earth with volcanic sulfur aerosol emissions. Geophysical Research Letters, 44(4):1938-1946, 2017.

[28] Peter Molnar. Late Cenozoic increase in accumulation rates of terrestrial sediment: How might climate change have affected erosion rates? Annual Review of Earth and Planetary Sciences, 32:67-89, 2004. ISSN 00846597. doi: 10.1146/annurev.earth. 32.091003.143456.

[29] Rebecca M. Flowers, Francis A. MacDonald, Christine S. Siddoway, and Rachel Havranek. Diachronous development of Great Unconformities before Neoproterozoic Snowball Earth. Proceedings of the National Academy of Sciences of the United States of America, 117(19):10172-10180, 2020. ISSN 10916490. doi: 10.1073/pnas.1913131117.

[30] C. P. Sturrock, R. M. Flowers, and F. A. Macdonald. The Late Great Unconformity of the Central Canadian Shield. Geochemistry, Geophysics, Geosystems, 22(6):e2020GC009567, jun 2021. ISSN 1525-2027. doi: 10.1029/2020gc009567.

[31] Jason W. Ricketts, Jacoup Roiz, Karl E. Karlstrom, Matthew T. Heizler, William R. Guenthner, and J. Michael Timmons. Tectonic controls on basement exhumation in the southern Rocky Mountains (United States): The power of combined zircon (U$\mathrm{Th}) / \mathrm{He}$ and K-feldspar 40Ar/39Ar thermochronology. Geology, 49(10):1187-1192, 2021. doi: 10.1130/g49141.1.

[32] Karl E. Karlstrom and J. Michael Timmons. Many unconformities make one 'Great Unconformity'. Special Paper of the Geological Society of America, 489:73-79, 2012. doi: 10.1130/2012.2489(04).

[33] Yannick Donnadieu, Frederic Fluteau, Gilles Ramstein, Catherine Ritz, and Jean Besse. Is there a conflict between the Neoproterozoic glacial deposits and the snowball Earth interpretation: An improved understanding with numerical modeling. Earth and Planetary Science Letters, 208(1-2):101-112, mar 2003 ISSN 0012821X. doi: 10.1016/S0012-821X(02)01152-4.
[34] Kalin T. McDannell and Rebecca M. Flowers. Vestiges of the Ancient: Deep-Time Noble Gas Thermochronology. Elements, 16(5):325-330, 2020. doi: 10.2138/gselements.16.5.325.

[35] K.T. McDannell. Methods and application of deep-time thermochronology: Insights from slowly cooled terranes of Mongolia and the North American craton. PhD thesis, Theses and Dissertations. 2721, Lehigh University, Bethlehem, Pennsylvania, 261 p., 2017. URL https://preserve.lehigh. edu/etd/2721.

[36] M S DeLucia, W R Guenthner, S Marshak, S N Thomson, and A K Ault. Thermochronology links denudation of the Great Unconformity surface to the supercontinent cycle and snowball Earth. Geology, 46(2):167-170, 2018.

[37] Kalin T. McDannell, David A. Schneider, Peter K. Zeitler, Paul B. O'Sullivan, and Dale R. Issler. Reconstructing deep-time histories from integrated thermochronology: An example from southern Baffin Island, Canada. Terra Nova, 31(3):189-204, 2019. doi: 10.1111/ter.12386.

[38] Peter K Zeitler. Argon diffusion in partially outgassed alkali feldspars: Insights from 40Ar/39Ar analysis. Chemical Geology: Isotope Geoscience section, 65(2):167-181, 1987. doi: 10.1016/ 0168-9622(87)90071-6.

[39] O M Lovera, Frank M Richter, and T Mark Harrison. The 40Ar/39Ar Thermochronometry for Slowly Cooled Samples Having a Distribution of Diffusion Domain Sizes. Journal of Geophysical Research, 94(B12):17917-17935, 1989.

[40] T Mark Harrison, Marty Grove, Oscar M Lovera, and Peter K Zeitler. Continuous Thermal Histories from Inversion of Closure Profiles. Reviews in Mineralogy and Geochemistry, 58(1):389409, 2005. doi: 10.2138/rmg.2005.58.15.

[41] David L Shuster, Rebecca M Flowers, and Kenneth A Farley. The influence of natural radiation damage on helium diffusion kinetics in apatite. Earth and Planetary Science Letters, 249 (3-4):148-161, 2006.

[42] Rebecca M. Flowers, Richard A. Ketcham, David L. Shuster, and Kenneth A. Farley. Apatite (U-Th)/He thermochronometry using a radiation damage accumulation and annealing model. Geochimica et Cosmochimica Acta, 73(8):2347-2365, 2009. ISSN 00167037. doi: 10.1016/j.gca.2009.01.015.

[43] William R. Guenthner, Peter W. Reiners, Richard A. Ketcham, Lutz Nasdala, and Gerald Giester. Helium diffusion in natural zircon: radiation damage, anisotropy, and the interpretation of zircon (U-Th)/He thermochronology. American Journal of Science, 313(3):145-198, 2013. ISSN 00029599. doi: 10.2475/ 03.2013.01.

[44] Emily H. G. Cooperdock, Richard A. Ketcham, and Daniel F. Stockli. Resolving the effects of 2-D versus 3-D grain measurements on apatite (U-Th)/He age data and reproducibility. Geochronology, 1(1):17-41, sep 2019. doi: 10.5194/ gchron-1-17-2019.

[45] Alexis K Ault, William R Guenthner, Amy C Moser, Gifford H Miller, and Kurt A Refsnider. Zircon grain selection reveals (de) coupled metamictization, radiation damage, and He diffusivity. Chemical Geology, 490:1-12, 2018.

[46] R L Fleischer, P B Price, and R M Walker. Tracks of charged particles in solids. Science, 149:383-393, 1965.

[47] Raymond A Donelick, Paul B O'Sullivan, and Richard A Ketcham. Apatite fission-track analysis. In Reviews in Mineralogy and Geochemistry, volume 58, pages 49-94. Mineralogical Society of America, 2005. ISBN 1529-6466. doi: 10.2138/rmg.2005.58.3. 
[48] A. J.W. Gleadow and I. R. Duddy. A natural long-term track annealing experiment for apatite. Nuclear Tracks, 5(1-2):169174, 1981. doi: 10.1016/0191-278X(81)90039-1.

[49] P F Green, I R Duddy, A J W Gleadow, P R Tingate, and G M Laslett. Thermal annealing of fission tracks in apatite: 1. A qualitative description. Chemical Geology: Isotope Geoscience Section, 59:237-253, 1986.

[50] P. F. Green, I. R. Duddy, A. J.W. Gleadow, P. R. Tingate, and G. M. Laslett. Fission-track annealing in apatite: Track length measurements and the form of the Arrhenius plot. Nuclear Tracks and Radiation Measurements (1982), 10(3):323-328, 1985. doi: 10.1016/0735-245X(85)90121-8.

[51] William D. Carlson, Raymond A. Donelick, and Richard A. Ketcham. Variability of apatite fission-track annealing kinetics: I. Experimental results. American Mineralogist, 84(9):12131223, 1999. ISSN 0003004X. doi: 10.2138/am-1999-0901.

[52] A. J.W. Gleadow, I. R. Duddy, P. F. Green, and J. F. Lovering. Confined fission track lengths in apatite: a diagnostic tool for thermal history analysis. Contributions to Mineralogy and Petrology, 94(4):405-415, 1986. ISSN 00107999. doi: 10.1007/BF00376334.

[53] R M Flowers, S A Bowring, and P W Reiners. Low long-term erosion rates and extreme continental stability documented by ancient (U-Th)/He dates. Geology, 34(11):925-928, 2006. doi: 10.1130/g22670a.1.

[54] Rebecca M Flowers. Exploiting radiation damage control on apatite $(\mathrm{U}-\mathrm{Th}) / \mathrm{He}$ dates in cratonic regions. Earth and Planetary Science Letters, 277(1-2):148-155, 2009. doi: 10.1016/j.eps1. 2008.10.005.

[55] Kalin T. McDannell, Peter K. Zeitler, and David A. Schneider. Instability of the southern Canadian Shield during the late Proterozoic. Earth and Planetary Science Letters, 490:100-109, 2018. ISSN 0012821X. doi: 10.1016/j.epsl.2018.03.012.

[56] Louise Miltich. Low Temperature Cooling History of Archean Gneisses and Paleoproterozic Granites of Southwestern Minnesota. Carleton College, Northfield, MN. Undergraduate thesis, 2005. URL https: //www. carleton.edu/departments/geol/Resources/ comps/CompsPDFfiles/2005/LouiseMiltich.pdf.

[57] Steven J Whitmeyer and Karl E Karlstrom. Tectonic model for the Proterozoic growth of North America. Geosphere, 3(4): 220-259, 2007.

[58] Stephen Marshak, Stefanie Domrois, Curtis Abert, Timothy Larson, Gary Pavlis, Michael Hamburger, Xiaotao Yang, Hersh Gilbert, and Chen Chen. The basement revealed: Tectonic insight from a digital elevation model of the Great Unconformity, USA cratonic platform. Geology, 45(5):391-394, 2017. ISSN 19432682. doi: 10.1130/G38875.1.

[59] J Michael Timmons, Karl E Karlstrom, Carol M Dehler, John W Geissman, and Matthew T Heizler. Proterozoic multistage (ca. 1.1 and $0.8 \mathrm{Ga}$ ) extension recorded in the Grand Canyon $\mathrm{Su}-$ pergroup and establishment of northwest- and north-trending tectonic grains in the southwestern United States. Geological Society of America Bulletin, 113(2):163-181, 2001. doi: 10.1130/0016-7606(2001)113<0163:pmcage >2.0.co;2.

[60] Christine Smith Siddoway and George E. Gehrels. Basementhosted sandstone injectites of Colorado: A vestige of the Neoproterozoic revealed through detrital zircon provenance analysis. Lithosphere, 6(6):403-408, 12 2014. ISSN 1947-4253. doi: 10.1130/L390.1.

[61] Christopher J. Potter, James A. Drahovzal, Michael L. Sargent, and John H. McBride. Proterozoic structure, cambrian rifting, and younger faulting as revealed by a regional seismic reflection network in the Southern Illinois Basin. Seismological Research Letters, 68(4):537-552, 1997. ISSN 00128287. doi: 10.1785/ gssrl.68.4.537.

[62] R. M. Flowers, K. H. Mahan, S. A. Bowring, M. L. Williams, M. S. Pringle, and K. V. Hodges. Multistage exhumation and juxtaposition of lower continental crust in the western Canadian Shield: Linking high-resolution U-Pb and40Ar/ 39Ar thermochronometry with pressure-temperature-deformation paths. Tectonics, 25(4):1-20, 2006. ISSN 02787407. doi: 10.1029/ 2005 TC001912.

[63] Kerry Gallagher. Transdimensional inverse thermal history modeling for quantitative thermochronology. Journal of Geophysical Research: Solid Earth, 117(B2), 2012.

[64] Richard A. Ketcham. Forward and inverse modeling of lowtemperature thermochronometry data. In Reviews in Mineralogy and Geochemistry, volume 58, pages 275-314. Mineralogical Society of America, 2005. doi: 10.2138/rmg.2005.58.11.

[65] Kalin T McDannell and Dale R Issler. Simulating sedimentary burial cycles - Part 1: Investigating the role of apatite fission track annealing kinetics using synthetic data. Geochronology, 3 (1):321-335, 2021. doi: 10.5194/gchron-3-321-2021.

[66] Alberto Malinverno and Victoria A. Briggs. Expanded uncertainty quantification in inverse problems: Hierarchical Bayes and empirical Bayes. Geophysics, 69(4):1005-1016, 72004. ISSN 00168033. doi: 10.1190/1.1778243.

[67] R H Rainbird, R A Stern, N Rayner, and C W Jefferson. Age, provenance, and regional correlation of the Athabasca Group, Saskatchewan and Alberta, constrained by igneous and detrital zircon geochronology. Bulletin - Geological Survey of Canada, 588:193, 2007

[68] M. E. Bickford, J. L. Wooden, and R. L. Bauer. SHRIMP study of zircons from Early Archean rocks in the Minnesota River Valley: Implications for the tectonic history of the Superior Province. Bulletin of the Geological Society of America, 118 (1-2):94-108, 2006. ISSN 00167606. doi: 10.1130/B25741.1.

[69] D L Southwick, G B Morey, and J H Mossler. Fluvial origin of the lower Proterozoic Sioux quartzite, southwestern Minnesota. Geological Society of America Bulletin, 97(12):1432-1441, 1986. ISSN 00167606. doi: 10.1130/0016-7606(1986)97<1432: FOOTLP $>2.0 . C O ; 2$.

[70] L. Gordon Medaris, Steven G. Driese, Gary E. Stinchcomb, John H. Fournelle, Seungyeol Lee, Huifang Xu, Lyndsay DiPietro, Phillip Gopon, and Esther K. Stewart. Anatomy of a sub-cambrian paleosol in Wisconsin: Mass fluxes of chemical weathering and climatic conditions in North America during formation of the Cambrian great unconformity. Journal of Geology, 126(3):261-283, 2018. ISSN 15375269. doi: 10.1086/697037.

[71] Mark A. Jirsa, Terrence J. Boerboom, V.W. Chandler, John H. Mossler, Anthony C. Runkel, and Dale R. Setterholm. S-21 Geologic Map of Minnesota-Bedrock Geology, 2011. URL https://hdl.handle.net/11299/101466.

[72] Robert H Rainbird, Larry M Heaman, and Grant Young. Sampling Laurentia: Detrital zircon geochronology offers evidence for an extensive Neoproterozoic river system originating from the Grenville orogen. Geology, 20(4):351-354, 1992. doi: 10.1130/0091-7613(1992)020<0351:SLDZGO>2.3.CO;2.

[73] B. R. Doe and M. H. Delevaux. Lead-isotope investigations in the minnesota river valley- Late-tectonic and posttectonic granites. Special Paper of the Geological Society of America, 182: 105-112, 1980. ISSN 00721077. doi: 10.1130/SPE182-p105. 
[74] Karl E. Karlstrom, Stephen S. Harlan, Michael L. Williams, James McLelland, John W. Geissman, and Karl Inge Åhäll. Refining Rodinia: Geologic evidence for the Australia-Western U.S. Connection in the Proterozoic. GSA Today, 9(10):2-7, 1999. ISSN 10525173. doi: 10.1130/gsat-1999-10-01-science.

[75] Katie J. Pevehouse, Dustin E. Sweet, Branimir Segvić, Charles C. Monson, Giovanni Zanoni, Stephen Marshak, and Melanie A. Barnes. Paleotopography controls weathering of Cambrian-age profiles beneath the great unconformity, St. Francois Mountains, SE Missouri, U.S.A. Journal of Sedimentary Research, 90(6): 629-650, 2020. ISSN 15271404. doi: 10.2110/JSR.2020.33.

[76] Kristin D. Bergmann, Seth Finnegan, Roger Creel, John M. Eiler, Nigel C. Hughes, Leonid E. Popov, and Woodward W. Fischer. A paired apatite and calcite clumped isotope thermometry approach to estimating Cambro-Ordovician seawater temperatures and isotopic composition. Geochimica et Cosmochimica Acta, 224: 18-41, 3 2018. ISSN 00167037. doi: 10.1016/j.gca.2017.11.015.

[77] TA Steven, E Evanoff, RH Yuhas, DW Bolyard, and SA Sonnenberg. Middle and late Cenozoic geomorphic development of the Front Range of Colorado. In Geologic History of the Colorado Front Range: Rocky Mountain Section, American Association of Petroleum Geologists, Field Trip Guidebook, pages 28-30. Rocky Mountain Association of Geologists, 1997.

[78] Christine Siddoway, Paul Myrow, and Elisa Fitz-Diaz. Strata, structures, and enduring enigmas: A 125th Anniversary appraisal of Colorado Springs geology. In L.D. Abbott and G.S. Hancock, editors, Classic Concepts and New Directions: Exploring 125 Years of GSA Discoveries in the Rocky Mountain Region, chapter 13, pages 331-356. Geological Society of America, 2013. doi: 10.1130/2013.0033(13).

[79] C. S. Siddoway, G. Palladino, G. Prosser, D. Freedman, and W. Cody Duckworth. Basement-hosted sand injectites: use of field examples to advance understanding of hydrocarbon reservoirs in fractured crystalline basement rocks. Geological Society, London, Special Publications, 493:493-2018, 7 2019. ISSN 0305-8719. doi: 10.1144/sp493-2018-140.

[80] Jordan L Jensen, Christine S Siddoway, Peter W Reiners, Alexis K Ault, Stuart N Thomson, and Matthew Steele-MacInnis. Single-crystal hematite (U-Th)/He dates and fluid inclusions document widespread Cryogenian sand injection in crystalline basement. Earth and Planetary Science Letters, 500:145-155, 2018.

[81] Y Goddéris, Y Donnadieu, A Nédélec, B Dupré, C Dessert, Aline Grard, G Ramstein, and L M François. The Sturtian 'snowball'glaciation: fire and ice. Earth and Planetary Science Letters, 211(1-2):1-12, 2003.

[82] T. M. Gernon, T. K. Hincks, T. Tyrrell, E. J. Rohling, and M. R. Palmer. Snowball Earth ocean chemistry driven by extensive ridge volcanism during Rodinia breakup. Nature Geoscience, 9 (3):242-248, 2016. ISSN 17520908. doi: 10.1038/ngeo2632.

[83] Amber Walsh, Thomas Ball, and David M. Schultz. Extreme sensitivity in Snowball Earth formation to mountains on PaleoProterozoic supercontinents. Scientific Reports, 9(1), 2019. ISSN 20452322. doi: 10.1038/s41598-019-38839-6.

[84] Andrew S. Merdith, Alan S. Collins, Simon E. Williams, Sergei Pisarevsky, John D. Foden, Donnelly B. Archibald, Morgan L. Blades, Brandon L. Alessio, Sheree Armistead, Diana Plavsa, Chris Clark, and R. Dietmar Müller. A full-plate global reconstruction of the Neoproterozoic. Gondwana Research, 50: 84-134, 2017. ISSN 1342937X. doi: 10.1016/j.gr.2017.04.001.

[85] Karl E Karlstrom, Samuel A Bowring, Carol M Dehler, Andrew H Knoll, Susannah M Porter, David J Des Marais, Arlo B
Weil, Zachary D Sharp, John W Geissman, and Maya B Elrick. Chuar Group of the Grand Canyon: Record of breakup of Rodinia, associated change in the global carbon cycle, and ecosystem expansion by 740 Ma. Geology, 28(7):619-622, 2000.

[86] E M Moores. Southwest US-East Antarctic (SWEAT) connection: a hypothesis. Geology, 19(5):425-428, 1991.

[87] Sergei A. Pisarevsky, Michael T.D. Wingate, Chris Mca Powell, Simon Johnson, and David A.D. Evans. Models of Rodinia assembly and fragmentation. Geological Society Special Publication, 206(1):35-55, 2003. ISSN 03058719. doi: 10.1144/GSL.SP.2003.206.01.04.

[88] David A.D. Evans. The palaeomagnetically viable, long-lived and all-inclusive Rodinia supercontinent reconstruction. Geological Society Special Publication, 327(1):371-404, 2009. ISSN 03058719. doi: 10.1144/SP327.16.

[89] Xianqing Jing, David A.D. Evans, Zhenyu Yang, Yabo Tong, Yingchao $\mathrm{Xu}$, and Heng Wang. Inverted South China: A novel configuration for Rodinia and its breakup. Geology, 49(4):463467, dec 2021. ISSN 19432682. doi: 10.1130/G47807.1.

[90] Karl E Karlstrom, Matt Heizler, and Mark C Quigley. Structure and 40Ar/39Ar K-feldspar thermal history of the Gold Butte block: Reevaluation of the tilted crustal section model. In Paul J Umhoefer, L Sue Beard, and Melissa A Lamb, editors, Miocene Tectonics of the Lake Mead Region, Central Basin and Range, pages 331-352. Geological Society of America Special Paper 463, Boulder, CO, United States, 2010. ISBN 9780813724638. doi: https://doi.org/10.1130/2010.2463(15).

[91] Ross N. Mitchell, Nan Zhang, Johanna Salminen, Yebo Liu, Christopher J. Spencer, Bernhard Steinberger, J. Brendan Murphy, and Zheng Xiang Li. The supercontinent cycle. Nature Reviews Earth and Environment, 2(5):358-374, apr 2021. doi: 10.1038/s43017-021-00160-0.

[92] J Brendan Murphy and R Damian Nance. Speculations on the mechanisms for the formation and breakup of supercontinents. Geoscience Frontiers, 4(2):185-194, 2013.

[93] Peter A Cawood, Robin A Strachan, Sergei A Pisarevsky, Dmitry P Gladkochub, and J Brendan Murphy. Linking collisional and accretionary orogens during Rodinia assembly and breakup: Implications for models of supercontinent cycles. Earth and Planetary Science Letters, 449:118-126, 2016.

[94] Michael Gurnis. Large-scale mantle convection and the aggregation and dispersal of supercontinents. Nature, 332(6166): 695-699, 1988.

[95] Nan Zhang, Zhuo Dang, Chuan Huang, and Zheng-Xiang Li. The dominant driving force for supercontinent breakup: Plume push or subduction retreat? Geoscience Frontiers, 9(4):9971007, 2018.

[96] Dwight C Bradley. Passive margins through earth history. EarthScience Reviews, 91(1-4):1-26, 2008.

[97] Don L Anderson. Hotspots, polar wander, Mesozoic convection and the geoid. Nature, 297(5865):391, 1982.

[98] Philip J. Heron and Julian P. Lowman. The impact of Rayleigh number on assessing the significance of supercontinent insulation. Journal of Geophysical Research: Solid Earth, 119(1):711733, jan 2014. ISSN 21699356. doi: 10.1002/2013JB010484.

[99] Andrew S. Merdith, Simon E. Williams, Sascha Brune, Alan S. Collins, and R. Dietmar Müller. Rift and plate boundary evolution across two supercontinent cycles. Global and Planetary Change, 173:1-14, feb 2019. ISSN 09218181. doi: 10.1016/j.gloplacha.2018.11.006. 
[100] L L Sloss. Sequences in the Cratonic Interior of North America Geological Society of America Bulletin, 74(2):93, 1963. doi: 10.1130/0016-7606(1963)74[93:sitcio]2.0.co;2.

[101] Peter M. Burgess, Michael Gurnis, and Louis Moresi. Formation of sequences in the cratonic interior of North America by interaction between mantle, eustatic, and stratigraphic processes. Bulletin of the Geological Society of America, 109(12):15151535, 1997. ISSN 00167606. doi: 10.1130/0016-7606(1997) $109<1515$ :FOSITC $>2.3$. CO; 2 .

[102] N Flament, M Gurnis, and R D Muller. A review of observations and models of dynamic topography. Lithosphere, 5(2):189-210, 2013. doi: 10.1130/1245.1.

[103] Jean Braun, François Guillocheau, Cécile Robin, Guillaume Baby, and Hielke Jelsma. Rapid erosion of the Southern African Plateau as it climbs over a mantle superswell. Journal of Geophysical Research: Solid Earth, 119(7):6093-6112, 2014

[104] Gregory A. Ruetenik, Robert Moucha, and Gregory D. Hoke. Landscape response to changes in dynamic topography. Terra Nova, 28(4):289-296, aug 2016. ISSN 13653121. doi: 10.1111/ ter. 12220 .

[105] J Braun, X Robert, and T Simon-Labric. Eroding dynamic topography. Geophysical Research Letters, 40(8):1494-1499, 2013. doi: $10.1002 / \mathrm{grl} .50310$.

[106] Jessica R. Stanley, Rebecca M. Flowers, and David R. Bell. Erosion patterns and mantle sources of topographic change across the southern African Plateau derived from the shallow and deep records of kimberlites. Geochemistry, Geophysics, Geosystems, 16(9):3235-3256, 2015. ISSN 15252027. doi: 10.1002/2015GC005969.

[107] Zheng-Xiang Li, X H Li, P D Kinny, and Jian Wang. The breakup of Rodinia: did it start with a mantle plume beneath South China? Earth and Planetary Science Letters, 173(3): 171-181, 1999.

[108] Zheng-Xiang Li, X H Li, P D Kinny, Jian Wang, Sheng Zhang, and Hanwen Zhou. Geochronology of Neoproterozoic syn-rift magmatism in the Yangtze Craton, South China and correlations with other continents: evidence for a mantle superplume that broke up Rodinia. Precambrian Research, 122(1-4):85-109, 2003.

[109] Yannick Donnadieu, Yves Goddéris, Gilles Ramstein, Anne Nédélec, and Joseph Meert. A 'snowball Earth' climate triggered by continental break-up through changes in runoff. Nature, 428 : 303-306, 2004. doi: 10.1038/nature02408.

[110] Yves Goddéris, Yannick Donnadieu, Céline Dessert, Bernard Dupré, Frédéric Fluteau, Louis M François, Joseph Meert, Anne Nédélec, and Gilles Ramstein. Coupled modeling of global carbon cycle and climate in the Neoproterozoic: links between Rodinia breakup and major glaciations. Comptes Rendus Geoscience, 339(3-4):212-222, 2007.

[111] Grant M Cox, Galen P Halverson, Ross K Stevenson, Michelle Vokaty, André Poirier, Marcus Kunzmann, Zheng-Xiang Li, Steven W Denyszyn, Justin V Strauss, and Francis A Macdonald. Continental flood basalt weathering as a trigger for Neoproterozoic Snowball Earth. Earth and Planetary Science Letters, 446 89-99, 2016.

[112] T. Cowton, P. Nienow, I. Bartholomew, A. Sole, and D. Mair. Rapid erosion beneath the Greenland ice sheet. Geology, 40(4): 343-346, 2012. ISSN 00917613. doi: 10.1130/G32687.1.

[113] B. Hallet, L. Hunter, and J. Bogen. Rates of erosion and sediment evacuation by glaciers: A review of field data and their implications. Global and Planetary Change, 12(1-4):213-235, 1996. ISSN 09218181. doi: 10.1016/0921-8181(95)00021-6.
[114] Michéle Koppes, Bernard Hallet, Eric Rignot, Jérémie Mouginot, Julia Smith Wellner, and Katherine Boldt. Observed latitudinal variations in erosion as a function of glacier dynamics. Nature, 526(7571):100-103, 2015. ISSN 14764687. doi: 10.1038/ nature 15385

[115] Francis A Macdonald, Nicholas L Swanson-Hysell, Yuem Park, Lorraine Lisiecki, and Oliver Jagoutz. Arc-continent collisions in the tropics set Earth's climate state. Science, 364(6436): 181-184, 2019.

[116] Simon J. Cook, Darrel A. Swift, Martin P. Kirkbride, Peter G Knight, and Richard I. Waller. The empirical basis for modelling glacial erosion rates. Nature Communications, 11(1):1-7, 12 2020. ISSN 20411723. doi: 10.1038/s41467-020-14583-8.

[117] M H P Bott. Origin of lithospheric tension causing basin formation. Philos. Trans. R. Soc. London, 305:319-324, 1982.

[118] Philip A Allen and John J Armitage. Cratonic basins. In Cathy Busby and Antonio Azor, editors, Tectonics of sedimentary basins: Recent advances, chapter 30, pages 602-620. Wiley, first edition, 2012. doi: 10.1002/9781444347166.ch30.

[119] Peter M. Burgess. Phanerozoic Evolution of the Sedimentary Cover of the North American Craton. In The Sedimentary Basins of the United States and Canada, volume 5, pages 39-75. Elsevier, 2019. ISBN 9780444638953. doi: 10.1016/B978-0-444-63895-3.00002-4.

[120] William A. White. Deep erosion by continental ice sheets. Bulletin of the Geological Society of America, 83(4):1037-1056, 1972. ISSN 19432674. doi: 10.1130/0016-7606(1972)83[1037: DEBCIS]2.0.CO;2.

[121] C. P. Gravenor. Erosion by continental ice sheets. American Journal of Science, 275(5):594-604, 5 1975. ISSN 0002-9599. doi: 10.2475/ajs.275.5.594.

[122] D. E. Sugden. Glacial Erosion by the Laurentide Ice Sheet. Journal of Glaciology, 20(83):367-391, 1978. ISSN 0022-1430. doi: $10.3189 / \mathrm{s} 0022143000013915$.

[123] M. Bell and E. P. Laine. Erosion of the Laurentide region of North America by glacial and glaciofluvial processes. Quaternary Research, 23(2):154-174, 1985. ISSN 10960287. doi: 10.1016/0033-5894(85)90026-2.

[124] Evan J. Gowan, Xu Zhang, Sara Khosravi, Alessio Rovere, Paolo Stocchi, Anna L.C. Hughes, Richard Gyllencreutz, Jan Mangerud, John Inge Svendsen, and Gerrit Lohmann. A new global ice sheet reconstruction for the past 80000 years. Nature Communications, 12(1):1-9, feb 2021. ISSN 20411723. doi: 10.1038/s41467-021-21469-w.

[125] Joseph M. Licciardi, Peter U. Clark, John W. Jenson, and Douglas R. Macayeal. Deglaciation of a soft-bedded Laurentide Ice Sheet. Quaternary Science Reviews, 17(4-5):427-448, jan 1998. ISSN 02773791. doi: 10.1016/S0277-3791(97)00044-9.

[126] Denis Lacelle, David A. Fisher, Stéphanie Coulombe, Daniel Fortier, and Roxanne Frappier. Buried remnants of the Laurentide Ice Sheet and connections to its surface elevation. Scientific Reports, 8(1):1-10, 12 2018. ISSN 20452322. doi: $10.1038 / \mathrm{s} 41598-018-31166-2$

[127] J. A. Fraser and L. P. Tremblay. Correlation of Proterozoic strata in the northwestern Canadian Shield. Canadian Journal of Earth Sciences, 6(1):1-9, 2 1969. ISSN 0008-4077. doi: 10.1139/e69-001.

[128] Dallas Abbott, David Sparks, Claude Herzberg, Walter Mooney, Anatoly Nikishin, and Yu Shen Zhang. Quantifying Precambrian crustal extraction: the root is the answer. Tectonophysics, 322 (1):163-190, 2000. 
[129] Stephan V. Sobolev and Michael Brown. Surface erosion events controlled the evolution of plate tectonics on Earth. Nature, 570(7759):52-57, 6 2019. ISSN 14764687. doi: 10.1038/ s41586-019-1258-4.

[130] Ross N. Mitchell, Thomas M. Gernon, Adam Nordsvan, Grant M. Cox, Zheng Xiang Li, and Paul F. Hoffman. Hit or miss: Glacial incisions of snowball Earth. Terra Nova, 31(4):381-389, 2019. ISSN 13653121. doi: 10.1111/ter.12400.

[131] T J Blackburn, S A Bowring, J T Perron, K H Mahan, F O Dudas, and K R Barnhart. An Exhumation History of Continents over Billion-Year Time Scales. Science, 335(6064):73-76, 2012.

[132] Ian W.D. Dalziel. Cambrian transgression and radiation linked to an Iapetus-Pacific oceanic connection? Geology, 42(11): 979-982, 2014. ISSN 19432682. doi: 10.1130/G35886.1.

[133] Richard A. Ketcham, Andrew Carter, Raymond A. Donelick, Jocelyn Barbarand, and Anthony J. Hurford. Improved modeling of fission-track annealing in apatite. American Mineralogist, 92 (5-6):799-810, 2007. ISSN 0003004X. doi: 10.2138/am.2007. 2281.

[134] William R. Guenthner, Peter W. Reiners, and Uttam Chowdhury. Isotope dilution analysis of $\mathrm{Ca}$ and $\mathrm{Zr}$ in apatite and zircon (U-Th)/He chronometry. Geochemistry, Geophysics, Geosystems, 17(5):1623-1640, 2016. ISSN 15252027. doi: 10.1002/2016GC006311.

[135] K. A. Farley, D. L. Shuster, and R. A. Ketcham. U and Th zonation in apatite observed by laser ablation ICPMS, and implications for the (U-Th)/He system. Geochimica et Cosmochimica Acta, 75(16):4515-4530, 2011. ISSN 00167037. doi: 10.1016/j.gca.2011.05.020.

[136] Alexis K Ault and Rebecca M Flowers. Is apatite U-Th zonation information necessary for accurate interpretation of apatite (U-Th)/He thermochronometry data? Geochimica et Cosmochimica Acta, 79:60-78, 2012. doi: 10.1016/j.gca.2011.11. 037.

[137] Peter W Reiners and Stefan Nicolescu. Measurement of parent nuclides for (U-Th)/He chronometry by solution sector ICP-MS. Technical report, University of Arizona, 2006. URL https://www.geo.arizona.edu/ reiners/ arhdl/arhdlrep1.pdf.

[138] Peter W Reiners, Terry L Spell, Stefan Nicolescu, and Kathleen A Zanetti. Zircon (U-Th)/He thermochronometry: He diffusion and comparisons with $40 \mathrm{Ar} / 39 \mathrm{Ar}$ dating. Geochimica et Cosmochimica Acta, 68(8):1857-1887, 2004.

[139] Kalin T. McDannell, Peter K. Zeitler, Darwin G. Janes, Bruce D. Idleman, and Annia K. Fayon. Screening apatites for (U-Th)/He thermochronometry via continuous ramped heating: He age components and implications for age dispersion. Geochimica et Cosmochimica Acta, 223:90-106, 2018. doi: 10.1016/j.gca. 2017.11.031. 